\title{
EXPERIMENTAL STUDY ON THE BEHAVIOR OF UNSATURATED COMPACTED SILT UNDER TRIAXIAL COMPRESSION
}

\author{
Fusao OKa ${ }^{\text {ii), }}$, TAKeshi KodakA ${ }^{\text {ii) }}$, Hirotaka SuZukiii), \\ Young Seok KIm ${ }^{\text {iv)}}$, Norisuke Nishimatsu ${ }^{\text {v) }}$ and SAyUri KImoto ${ }^{\text {i) }}$
}

\begin{abstract}
Most of the experimental investigations conducted on unsaturated soil have been performed under a constant air pressure. Changes in air pressure during deformation are in some cases important in practice. For example, in order to explain the stability problems of embankments during earthquakes and seepage flow, and grounds containing gas associated with the dissociation of methane hydrates, it is necessary to consider the interaction between the soil and the pore fluids. In the present study, we carried out fully undrained tests as well as drained tests, namely, constant water and constant air shearing tests. We performed the fully undrained tests using an air-controlled valve to measure the pore air pressure. For the stress variables of the unsaturated soil, skeleton stress values were used to describe the experimental results. From triaxial compression tests on silty soil, we found that the initial suction, the confining pressure, and the strain rate of unsaturated soil strongly influence the stress-strain behavior of unsaturated silt.
\end{abstract}

Key words: laboratory tests, silt, suction, triaxial compression tests, unsaturated soil (IGC: D6)

\section{INTRODUCTION}

Many laboratory tests have been conducted on unsaturated soil under a constant air pressure. However, the drained conditions for water and air cannot always be attained in engineering problems. For example, the air pressure in river embankments increases during the seepage process and may vary during soil compaction. Yamamura (1971) indicated that air can become trapped in parts of embankments during heavy rains or flooding. In the dissociation of methane hydrates that may occur during the development of methane gas in the ground, even subsurface sea ground (Kimoto et al., 2007) becomes unsaturated with high gas pressure. In addition, pore air and pore water cannot efficiently flow out from the soil skeleton during earthquakes. In these cases, the air pressure changes under the partially drained conditions; hence, it is necessary to investigate the air-water-soil interaction. This means that constant water and constant air content tests are needed to accurately verify the numerical models of unsaturated soil for general boundary conditions.

For this reason, we have conducted triaxial tests on silty clay under fully undrained conditions for water and air in which both the water content and the air content are constant; that is, the mass of water and air are constant in the specimen. For simplicity, we can call this the "fully undrained condition".

Since neither pore water nor pore air can flow out from the soil in the fully undrained tests, both the pore-water pressure and the pore-air pressure have to be accurately measured. In the present study, we have performed fully undrained tests, i.e., constant pore-water content and constant pore-air content tests, using an air pressureoperated valve located close to the cap of the cell to measure the pore-air pressure. We have used the skeleton stress, which is equivalent to the average skeleton stress originally adopted by Jommi (2000), instead of the net stress, to describe the results of the tests on the unsaturated soil.

The outline of the present paper is as follows. Firstly, the stress variables used in this study are presented. Secondly, a method for measuring the volume changes in unsaturated soil and a method for measuring the air pressure are introduced. Then, the results of triaxial compression tests on unsaturated soil under different drainage conditions are presented. These tests have been performed in order to investigate the changes in suction and pore pressure. Finally, the effects of the drainage conditions, the suction, the confining pressure, and the strain rate on the behavior of unsaturated soil are discussed using the test results.

i) Department of Civil and Earth Resources Engineering, Kyoto University, Kyoto, Japan (foka@mbox.kudpc.kyoto-u.ac.jp).

ii) Department of Civil Engineering, Meijo University, Nagoya, Japan.

ii) Osaka Gas, Osaka, Japan (formerly Master Course Student of Kyoto University, Japan).

iv) Korean Institute of Construction Technology, Seoul, Korea (formerly Doctoral Course Student of Kyoto University, Japan).

v) Osaka City, Osaka, Japan (formerly Master Course Student of Kyoto University, Japan).

The manuscript for this paper was received for review on November 11, 2008; approved on September 29, 2009.

Written discussions on this paper should be submitted before September 1, 2010 to the Japanese Geotechnical Society, 4-38-2, Sengoku, Bunkyo-ku, Tokyo 112-0011, Japan. Upon request the closing date may be extended one month. 


\section{STRESS VARIABLES}

To analyze unsaturated soil, it is necessary to choose appropriate stress variables. Stress variables for suction and the excess total stress over the air pressure (or the excess total stress over the water pressure) have been used to describe the mechanical behavior of unsaturated soil (Bishop, 1960; Fredlund and Morgenstern, 1977; Alonso et al., 1990; Wheeler and Sivakumar, 1995). Karube and Kawai (2001) used a generalized Bishop's stress, while Kohgo et al. (1993) and Loret and Khalili (2000) adopted an effective stress that includes constitutive parameters. Recently, the term "effective stress," or "average skeleton stress," has been used when considering the mixture theory (Bolzon et al., 1996; Jommi, 2000; Ehlers et al., 2004). The average skeleton stress is defined as the difference in stress between the total stress and the average pore pressure composed of pore-water pressure and pore-air pressure. A mathematical formula of the average skeleton stress is equal to the effective stress, or the generalized effective stress, for unsaturated soil (Bolzon et al., 1996; Ehlers et al., 2004; Nuth and Laloui, 2008). However, it seems that the term "effective" is not appropriate because we need suction in order to describe the behavior of unsaturated soil with skeleton stress. In addition, it is better to refer to the average skeleton stress simply as "skeleton stress" to avoid confusing the average skeleton stress with the mean skeleton stress.

The stress parameters used in the description of the experimental results are introduced below. The soil suction, as quantified in terms of relative humidity, is commonly called "total suction." It has two components, namely, matric suction and solute suction. The solute suction can be disregarded because its value is less than that of the matric suction. The total suction usually equals the matric suction in geotechnical problems (Aitchison, 1960; Coleman, 1962).

The matric suction, simply referred to as the suction in this study, is defined as

$$
\text { Suction } s: s=u_{\mathrm{a}}-u_{\mathrm{w}}
$$

where $u_{\mathrm{a}}$ is the pore-air pressure and $u_{\mathrm{w}}$ is the pore-water pressure.

In order to describe the experimental results for the unsaturated soil in this study, we use the skeleton stress.

Definitions for the skeleton stress and the average pore fluid pressure are given as follows:

$$
\begin{aligned}
& \sigma_{\mathrm{ij}}^{\prime}=\sigma_{\mathrm{ij}}-P^{F} \delta_{\mathrm{ij}} \\
& P^{F}=S_{\mathrm{r}} u_{\mathrm{w}}+\left(1-S_{\mathrm{r}}\right) u_{\mathrm{a}}
\end{aligned}
$$

where $\sigma_{\mathrm{ij}}^{\prime}$ is the skeleton stress, $u_{\mathrm{w}}$ and $u_{\mathrm{a}}$ are the porewater pressure and the pore-gas pressure, respectively, $S_{\mathrm{r}}$ is the degree of saturation, and $P^{F}$ is the average pore pressure.

The adoption of skeleton stress represents a natural extension of the mixture theory to unsaturated soil (e.g., Kim et al., 2005; Oka et al., 2006; Oka et al., 2008). Therefore, it is possible to formulate a model for unsaturated soil starting from a model for saturated soil by sub- stituting the skeleton stress for the effective stress. In addition, we have incorporated the suction into the constitutive model (e.g., Oka et al., 2008). This indicates the use of a plural number of stress variables, i.e., skeleton stress and suction. A stress variable similar to that in Eq. (2) has been used by several researchers, such as Bolzon et al. (1996), Houlsby (1997), Jommi (2000), Gallipoli et al. (2002), Gallipoli et al. (2003), Ehlers et al. (2004), Wheeler et al. (2003), and Nuth and Laloui (2008). Bolzon et al. (1996), Ehlers et al. (2004), and Nuth and Laloui (2008) called it the effective stress, or the generalized effective stress. Wheeler, Sharma, and Buisson (2003) used the name "Bishop's stress" for the effective stress or the average skeleton stress. Herein, we refer to it as the skeleton stress, not the effective stress, because we take both the skeleton stress and suction into account.

\section{DESCRIPTION OF THE TEST DEVICE}

A schematic figure of the triaxial test apparatus used in this study is shown in Fig. 1(a). We employed a lucid acrylic cell so that the behavior of the specimens during the tests could be observed from outside the triaxial cell. The vertical load of the soil specimens was measured by the inner load cell set up between the loading rod and the top cap of the triaxial cell. Cell pressure was supplied by air pressure and was measured by a pressure gauge set on the outside of the triaxial cell. The axial displacement was measured by a proximity transducer for low levels of axial strain of less than $0.1 \%$, and by a local vertical deformation transducer (LVDT) for medium to high levels of strain. A differential pressure transducer was used to measure the changes in volume of the pore water.

The above-mentioned testing equipment and arrangements are commonly used for fully saturated soils. The conventional triaxial apparatus was modified, therefore, to prepare the unsaturated soil for testing. The presence of air in the pores made the testing procedure and the techniques more complex than for fluid-saturated soil. The most important and yet also the most difficult part of testing the unsaturated soil was that the pore-air pressure and the pore-water pressure had to be measured and controlled independently. In addition, it was necessary to measure the changes in volume during the tests.

The triaxial cell used in this study for testing the unsaturated soil is illustrated in Fig. 1(b). In order to separate the routes for the measurement and the control of the pore-air pressure and the pore-water pressure, a polyflon filter and a ceramic disc were applied. The polyflon filter was placed on the top of each specimen to cut off the flow of water. The pore-air pressure that passed through the polyflon filter was measured by a pressure gauge. The ceramic disc was installed in the lower pedestal to cut off the flow of air. The pore-water pressure was measured by a differential pressure transducer at the bottom of the specimen. The air entry value (A.E.V.) of the ceramic disc was $200 \mathrm{kPa}$.

The changes in volume of each specimen during the triaxial tests were evaluated by measuring the lateral dis- 


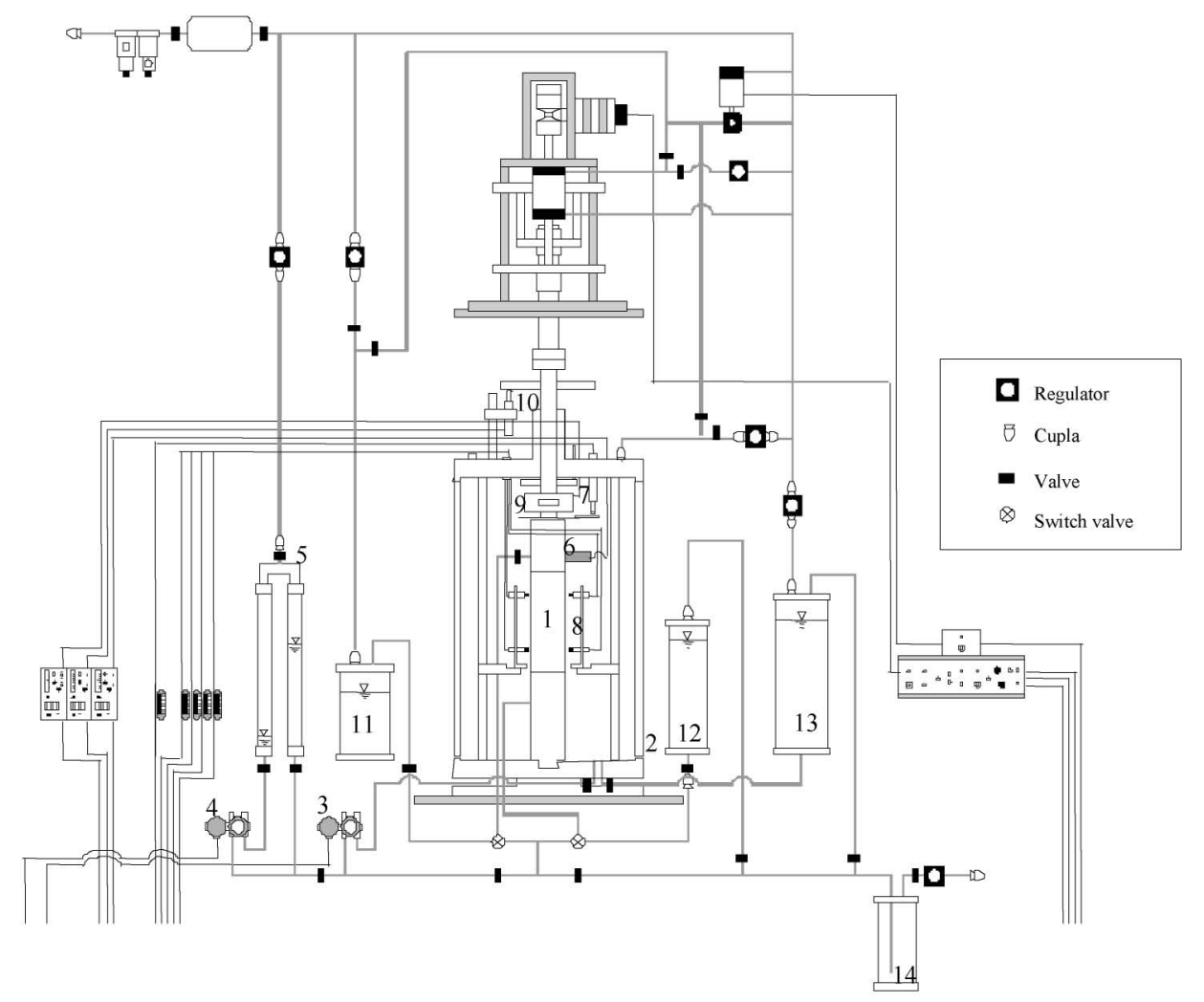

\begin{tabular}{|c|l|c|l|}
\hline 1 & Specimen & 8 & Proximeter (lateral displacement) \\
\hline 2 & Cell & 9 & Load cell \\
\hline 3 & Differential pressure transducer (restricted pressure) & 10 & Displacement transducer \\
\hline 4 & Differential pressure transducer (drained water) & 11 & Trap tank (upper) \\
\hline 5 & Burette & 12 & Deaired water tank (lower) \\
\hline 6 & Pressure transducer (pore-air pressure) & 13 & Cell water tank \\
\hline 7 & Proximeter (axial displacement) & 14 & Vacuum tank \\
\hline
\end{tabular}

Fig. 1(a). Schematic figure of the triaxial test apparatus

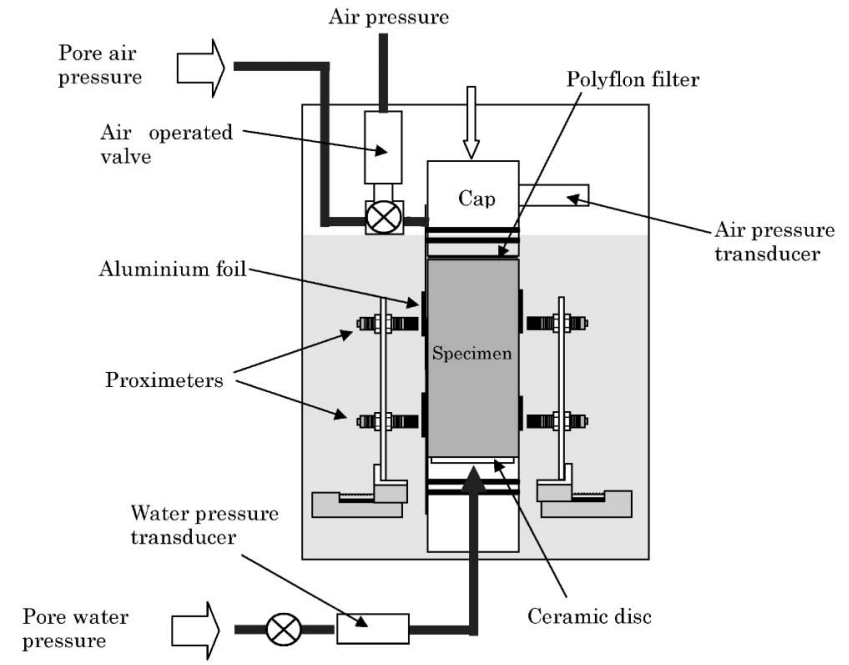

Fig. 1(b). Schematic figure of the triaxial cell

placements of the two sides of the specimen with four proximity transducers. Aluminum foil was used as a target for the proximity transducers. The main advantage of this method is that changes in volume can be obtained without any contact with the specimen. The proximity transducers used in this study can be controlled by lateral movements from outside the triaxial cell.

Fully undrained tests are special tests for unsaturated soil. Since it is difficult to control the pore-air pressure, this kind of experimental research has, to our knowledge, never been performed before. In the fully undrained tests, no pore air or pore water are allowed to flow out in the shearing process. In other words, the drainage valves for pore air and pore water are kept closed during shearing. Fully undrained loading causes further developments of excess pore-air pressure and pore-water pressure. The volume of the soil specimen may not remain constant during the shearing process; it may change due to the compression of pore air.

In particular, an accurate measurement of the pore-air pressure of the specimen is important in the tests. Therefore, we improved the system for the purpose of taking measurements and controlling of the pore-air pressure levels (Suzuki et al., 2006). As mentioned above, a schematic figure of the modified triaxial cell used in the fully undrained tests is shown in Fig. 1(b). The pore-air pressure passing through the polyflon filter was measured from the top of the specimen by a pressure gauge installed 
in the triaxial cell. In addition, fully undrained conditions during shearing were controlled by an air-operated valve installed in Fig. 1(b). This valve is called a "Diaphragm valve with an air actuator"; it is controlled by air pressure. This means we can shut off the valve by applying air pressure to the outside of the valve. In this study, in order to close the line for controlling the air pressure of the specimen, we applied an air pressure of $500 \mathrm{kPa}$ through a tube which is connected to the top of the valve illustrated in Fig. 1(b). The amount of the space between the air pressure gauge and the top of the specimen is very small; for example, the ratio of the air volume of the above space to the volume to the air contained in the specimen was $1.2 \%$, and the volume is $0.684 \mathrm{~cm}^{3}$ when the saturation was $46.6 \%$. As mentioned in the description of the test device, the pore-water pressure was measured from the bottom of the specimen by a differential pressure transducer.

\section{CALIBRATION PROCEDURE FOR MEASURING THE CHANGES IN VOLUME}

The general method for measuring the changes in volume during drained triaxial tests on saturated specimens is to measure the quantity of the water expelled or absorbed. In the case of unsaturated soil, changes in volume occur due to the drainage of a mixture of air and water. Bishop and Henkel (1962) and Matyas (1967) developed a procedure to measure the volume of both fluid phases using two burettes. However, this method is not thought to produce accurate measurements of the changes in volume due to the effects of compressibility and capillarity in the air bubbles. Over the years, several techniques have been proposed to address the shortfalls of this procedure. One of them consists of measuring the effect of sample volume changes on the surrounding triaxial cell liquid by using double-walled triaxial cells (Bishop and Donald, 1961; Sivakumar, 1993). Other methods for measuring the overall volume changes in unsaturated soil include performing direct measurements of the axial and the radial deformation of the specimen using the internal LVDT, Hall effect transducers (Clayton and Khatrush, 1986), non-contacting transducers located around the specimen (Cole, 1978; Khan and Hoag, 1979), strain gauges (Lo Presti et al., 1995; Kolymbas and Wu, 1989), opto-electronic sensors (Baumgartl et al., 1995), laser techniques (Romero et al., 1997), and image processing (Macari et al., 1997; Rifa'i et al., 2002).

This study was carried out by placing non-contacting transducers around the specimens, as shown in Fig. 1(a). Changes in the diameter of the specimens during the testing were measured with these four proximity transducers (proximeters). As a result, the average lateral strain was obtained. The volumetric strain, $\varepsilon_{\mathrm{v}}$, is given as follows:

$$
\varepsilon_{\mathrm{v}}=\varepsilon_{\mathrm{a}}+2 \varepsilon_{\mathrm{r}}
$$

where $\varepsilon_{\mathrm{a}}$ is the axial strain and $\varepsilon_{\mathrm{r}}$ is the average lateral strain measured by the proximity transducers.

Before the tests, a calibration procedure for changes in

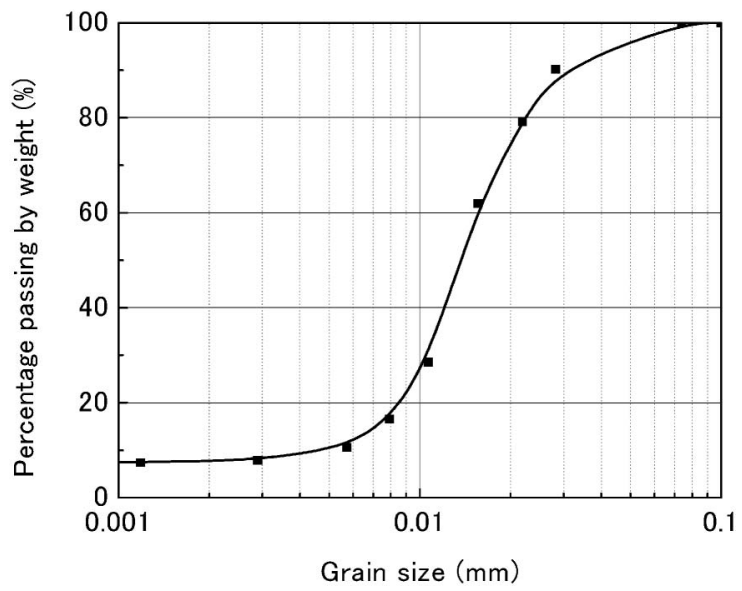

Fig. 2. Grain size accumulation curve

volume was performed using saturated soil in order to determine the appropriate positions for the proximeters (Kim, 2004; Nishimatsu, 2004).

\section{PHYSICAL CHARACTERISTICS OF THE SOIL TESTED}

In the present study, the soil used for the triaxial compression tests is DL clay (the commercial name). Dried and powdered DL clay consists of Kaolinite and silica. Kaolinite and silica stone are used as agricultural chemicals. DL clay is homogeneous and easy to obtain. It is larger in grain size than average clay and is composed of $90 \%$ silt and $10 \%$ clay. The soil's index properties are $W_{\mathrm{L}}$ $=\mathrm{NP}, I_{\mathrm{p}}=\mathrm{NP}$, and $G_{\mathrm{s}}=2.65$. The soil is classified as having Mo-Low compressibility (ML) according to the Japanese Geotechnical Society (JGS). The grain size distribution of DL clay is represented by the grading curve in Fig. 2, which shows that about $90 \%$ of the soil particles are silt.

\section{PREPARATION OF THE SPECIMENS AND TESTING PROCEDURE}

The specimens used in the present study were prepared by the compaction method. Prior to performing the compaction, the dry DL clay, with a particle density (specific gravity) of 2.65 , was mixed well with water to make up $20 \%$ of the water content. Then, the mixed wet DL clay was compacted statically in a cylindrical mold, $50 \mathrm{~mm}$ in diameter, to obtain the best possible standard homogeneity; we used a single static compaction technique not used the usual multi-layer compaction methods in sample preparation. The void ratio of the specimens was around 1.1. All the specimens used in this experimental study were $50 \mathrm{~mm}$ in diameter and $100 \mathrm{~mm}$ in height. After compaction, the measured pore-water pressure levels were around -18 to $-20 \mathrm{kPa}$ for all the samples. This means that the preparation procedure was always followed carefully in order to maintain a suction state of approximately $20 \mathrm{kPa}$ on the compacted samples. The 
dry density of the specimens after the compaction was around $1.3 \mathrm{~g} / \mathrm{cm}^{3}$.

\section{EXPERIMENTAL RESULTS}

\section{Drainage/Water-Absorption Process}

Before the shearing tests, the drainage/water-absorption process, which can also be called the "equalization stage," was performed by drainage or water absorption under cell pressure and the initial suction. The soil specimens were allowed to drain during the application of the cell pressure, and then were allowed to drain/absorb water during the application of the initial suction. As mentioned in the previous section, the suction measured in each specimen after compaction was around $20 \mathrm{kPa}$. After reaching a cell pressure of $270 \mathrm{kPa}$ and a pore-air pressure of $250 \mathrm{kPa}$, the measured pore-water pressure was around $230 \mathrm{kPa}$ for all the samples. The suction was then increased and decreased. In the final stage, the cell pressure was increased to specific values. The paths in the suction-cell pressure space during the drainage/water-absorption process are illustrated in Fig. 3.

A high initial suction was applied by decreasing the pore-water pressure levels. For specimens with lower suction levels, on the other hand, the initial suction was controlled by increasing the pore-water pressure. The test conditions for all the specimens are summarized in Table 1. Table 2 illustrates all the specimen data before the drainage/water-absorption process. In the tests, we maintained pore air pressure at a constant value of 250 $\mathrm{kPa}$ mainly because we utilized pore water pressure of more than $100 \mathrm{kPa}$. From a technical point of view the authors think that a rather high value of pore water pressure is preferable to accurately measure the positive and negative pore water pressures. The air pressure of 250 $\mathrm{kPa}$ is higher than the air entry value of $200 \mathrm{kPa}$ of the ceramic disk used in the experiment. Hence, in the preparatory tests, we confirmed no air infiltration during the tests. This is probably due to the net pressure (difference between the air pressure and the water pressure) being less than the air entry value. If we had used a ceramic disc with a higher A.E.V., it would have taken more

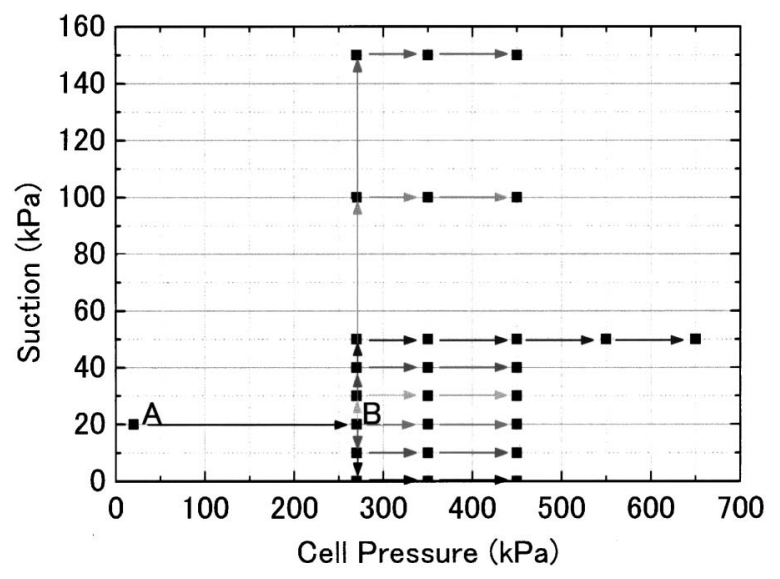

Fig. 3. Stress paths during the drainage/water-absorption process time for consolidation.

Figure 4 represents the drainage or the water absorption at different levels of initial suction and a cell pressure of $450 \mathrm{kPa}$. As shown in this figure, similar behavior under the same initial suction is obtained. The amount of drained water grew larger with an increase in the initial suction. The drainage of water occurred when the specimens were tested under initial suction levels of more than $20 \mathrm{kPa}$, i.e., 20, 30, 40, 50, 100, and $150 \mathrm{kPa}$. However, water absorption occurred when the specimens were tested under the initial suction level of $20 \mathrm{kPa}$, i.e., at 0 and $10 \mathrm{kPa}$. Water absorption occurred when the initial suction was lower than it was just after the compaction of the samples.

Therefore, when the initial suction was higher than the suction after compaction, namely, at 30,40, 50, 100, and

Table 1. Test conditions for all unsaturated soil specimens

\begin{tabular}{|c|c|c|c|c|c|}
\hline No. & D150-1 & D100-1 & D50-1 & D50-3-1 & D50-3-2 \\
\hline Initial suction $(\mathrm{kPa})$ & 150 & 100 & 50 & 50 & 50 \\
\hline Strain rate $(\% / \mathrm{min})$ & 0.05 & 0.05 & 0.05 & 0.05 & 0.05 \\
\hline Cell pessure $(\mathrm{kPa})$ & 450 & 450 & 450 & 650 & 350 \\
\hline Pore air pressure $(\mathrm{kPa})$ & 250 & 250 & 250 & 250 & 250 \\
\hline Pore water pressure $(\mathrm{kPa})$ & 100 & 150 & 200 & 200 & 200 \\
\hline Confining pressure $(\mathrm{kPa})$ & 200 & 200 & 200 & 400 & 100 \\
\hline No. & D40-1 & D30-1 & D20-1 & D10-1 & D0-1 \\
\hline Initial suction (kPa) & 40 & 30 & 20 & 10 & 0 \\
\hline Strain rate $(\% / \mathrm{min})$ & 0.05 & 0.05 & 0.05 & 0.05 & 0.05 \\
\hline Cell pessure $(\mathrm{kPa})$ & 450 & 450 & 450 & 450 & 450 \\
\hline Pore air pressure $(\mathrm{kPa})$ & 250 & 250 & 250 & 250 & 250 \\
\hline Pore water pressure $(\mathrm{kPa})$ & 210 & 220 & 230 & 240 & 250 \\
\hline Confining pressure $(\mathrm{kPa})$ & 200 & 200 & 200 & 200 & 200 \\
\hline
\end{tabular}

\begin{tabular}{c|c|c|c|c|c}
\hline No. & U100-1 & U50-1 & U50-2-1 & U50-2-2 & U50-3 \\
\hline Initial suction $(\mathrm{kPa})$ & 100 & 50 & 50 & 50 & 50 \\
\hline Strain rate $(\% / \mathrm{min})$ & 0.5 & 0.5 & 0.75 & 0.05 & 0.5 \\
\hline Cell pessure $(\mathrm{kPa})$ & 450 & 450 & 450 & 450 & 350 \\
\hline Pore air pressure $(\mathrm{kPa})$ & 250 & 250 & 250 & 250 & 250 \\
\hline Pore water pressure $(\mathrm{kPa})$ & 150 & 200 & 200 & 200 & 200 \\
\hline Confining pressure $(\mathrm{kPa})$ & 200 & 200 & 200 & 200 & 100 \\
\hline
\end{tabular}

\begin{tabular}{c|c|c|c}
\hline No. & $\mathrm{U} 30-1$ & $\mathrm{U} 10-1$ & $\mathrm{U} 0-1$ \\
\hline Initial suction $(\mathrm{kPa})$ & 30 & 10 & 0 \\
\hline Strain rate $(\% / \mathrm{min})$ & 0.5 & 0.5 & 0.5 \\
\hline Cell pessure $(\mathrm{kPa})$ & 450 & 450 & 450 \\
\hline Pore air pressure $(\mathrm{kPa})$ & 250 & 250 & 250 \\
\hline Pore water pressure $(\mathrm{kPa})$ & 220 & 240 & 250 \\
\hline Confining pressure $(\mathrm{kPa})$ & 200 & 200 & 200 \\
\hline
\end{tabular}


Table 2. Specimen data before the drainage/water-absorption process

\begin{tabular}{|c|c|c|c|c|c|}
\hline No. & D150-1 & D100-1 & D50-1 & D50-3-1 & D50-3-2 \\
\hline Saturation $S_{\mathrm{r}}(\%)$ & 47.08 & 47.21 & 47.01 & 46.94 & 47.03 \\
\hline Water content $w(\%)$ & 20.01 & 20.03 & 20.00 & 19.94 & 19.94 \\
\hline Void ratio $e$ & 1.13 & 1.12 & 1.13 & 1.13 & 1.12 \\
\hline No. & D40-1 & D30-1 & D20-1 & D10-1 & D0-1 \\
\hline Saturation $S_{\mathrm{r}}(\%)$ & 47.11 & 47.09 & 46.70 & 46.99 & 47.11 \\
\hline Water content $w(\%)$ & 19.96 & 20.06 & 19.81 & 19.95 & 20.06 \\
\hline Void ratio $e$ & 1.12 & 1.13 & 1.12 & 1.12 & 1.13 \\
\hline
\end{tabular}

\begin{tabular}{c|r|r|r|r|r}
\hline No. & $\mathrm{U} 100-1$ & $\mathrm{U} 50-1$ & $\mathrm{U} 50-2-1$ & $\mathrm{U} 50-2-2$ & $\mathrm{U} 50-3$ \\
\hline Saturation $S_{\mathrm{r}}(\%)$ & 47.05 & 47.37 & 47.54 & 47.18 & 47.15 \\
\hline Water content $w(\%)$ & 19.97 & 20.12 & 20.17 & 20.00 & 19.99 \\
\hline Void ratio $e$ & 1.13 & 1.13 & 1.12 & 1.12 & 1.12 \\
\hline
\end{tabular}

\begin{tabular}{c|r|r|r}
\hline No. & \multicolumn{1}{|c|}{$\mathrm{U} 30-1$} & $\mathrm{U} 10-1$ & $\mathrm{U} 0-1$ \\
\hline Saturation $S_{\mathrm{r}}(\%)$ & 47.08 & 47.13 & 47.30 \\
\hline Water content $w(\%)$ & 19.98 & 20.04 & 20.07 \\
\hline Void ratio $e$ & 1.12 & 1.13 & 1.12 \\
\hline
\end{tabular}

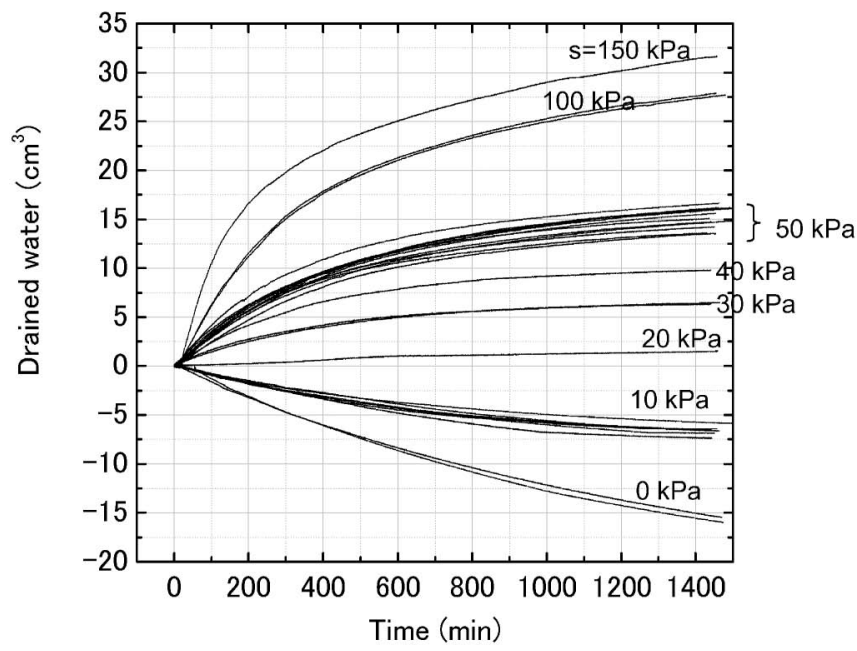

Fig. 4. Drained water/absorbed water during the drainage/water-absorption process

$150 \mathrm{kPa}$, initial suction was controlled by decreasing the pore-water pressure levels. On the other hand, at lower suction levels, initial suction was controlled by increasing the pore-water pressure.

The changes in volume during the drainage/water-absorption tests are shown in Fig. 5. As can be observed from this figure, the volumetric strain reduced with increases in the initial suction. The results show that little or no volumetric strain occurred until the loading of the cell pressure, and that a large instantaneous decrease in volume was brought about by the application of the load.

Figure 6 shows the changes in void ratio against the

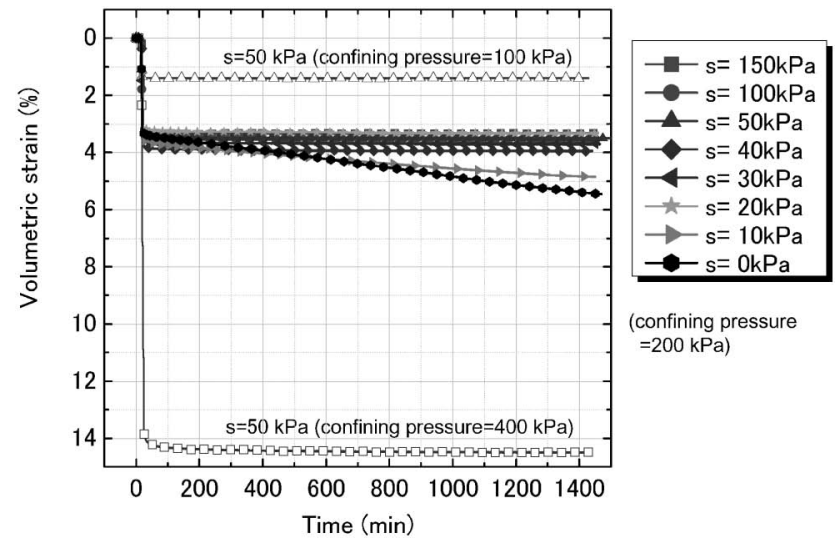

Fig. 5. Changes in volume during the drainage/water-absorption process

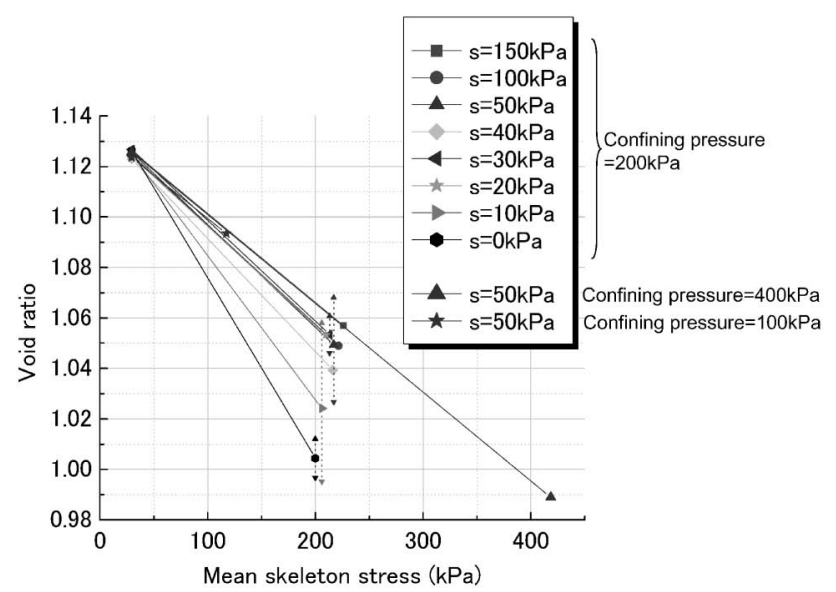

Fig. 6. Changes in void ratio during the drainage/water-absorption process

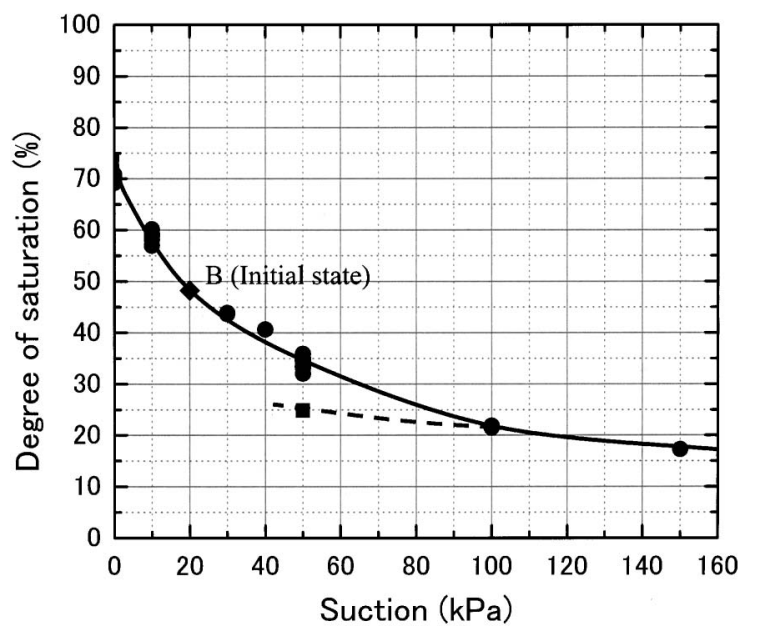

Fig. 7. Water retention curve/Soil water characteristic curve

mean skeleton stress during the drainage/water-absorption process. It can be seen that the slope tends to decrease with an increase in the initial suction. A clear decrease in compressibility is observed when the suction 
Table 3. Specimen data after the drainage/water-absorption process

\begin{tabular}{|c|c|c|c|c|c|}
\hline No. & D150-1 & D100-1 & D50-1 & D50-3-1 & D50-3-2 \\
\hline Volumetric strain (\%) & 2.40 & 3.58 & 2.81 & 6.43 & 1.40 \\
\hline Drained water $\left(\mathrm{cm}^{3}\right)$ & 31.64 & 27.71 & 16.18 & 15.05 & 13.59 \\
\hline Saturation $S_{\mathrm{r}}(\%)$ & 17.27 & 21.83 & 33.13 & 36.87 & 34.78 \\
\hline Water content $w(\%)$ & 7.01 & 8.63 & 13.35 & 13.76 & 14.36 \\
\hline Void ratio $e$ & 1.06 & 1.05 & 1.07 & 0.99 & 1.09 \\
\hline No. & D40-1 & D30-1 & D20-1 & D10-1 & D0-1 \\
\hline Volumetric strain (\%) & 3.94 & 3.20 & 3.33 & 4.45 & 5.46 \\
\hline Drained water $\left(\mathrm{cm}^{3}\right)$ & 9.78 & 6.32 & 1.53 & -6.45 & -15.48 \\
\hline Saturation $S_{\mathrm{r}}(\%)$ & 40.66 & 43.62 & 48.26 & 58.12 & 69.19 \\
\hline Water content $w(\%)$ & 15.94 & 17.46 & 19.18 & 22.60 & 26.43 \\
\hline Void ratio $e$ & 1.04 & 1.06 & 1.05 & 1.03 & 1.01 \\
\hline
\end{tabular}

\begin{tabular}{c|r|r|r|r|r}
\hline No. & U100-1 & U50-1 & U50-2-1 & U50-2-2 & U50-3 \\
\hline Volumetric strain $(\%)$ & 3.54 & 2.80 & 3.67 & 3.80 & 1.42 \\
\hline Drained water $\left(\mathrm{cm}^{3}\right)$ & 27.89 & 16.04 & 16.04 & 16.66 & 13.57 \\
\hline Saturation $S_{\mathrm{r}}(\%)$ & 21.50 & 33.61 & 34.37 & 33.43 & 34.93 \\
\hline Water content $w(\%)$ & 8.52 & 13.52 & 13.57 & 13.15 & 14.41 \\
\hline Void ratio $e$ & 1.05 & 1.07 & 1.05 & 1.04 & 1.09 \\
\hline
\end{tabular}

\begin{tabular}{c|r|r|r}
\hline No. & U30-1 & U10-1 & \multicolumn{1}{c}{ U0-1 } \\
\hline Volumetric strain $(\%)$ & 3.70 & 5.30 & 6.00 \\
\hline Drained water $\left(\mathrm{cm}^{3}\right)$ & 6.47 & -6.51 & -15.96 \\
\hline Saturation $S_{\mathrm{r}}(\%)$ & 43.89 & 59.36 & 70.81 \\
\hline Water content $w(\%)$ & 17.32 & 22.72 & 26.63 \\
\hline Void ratio $e$ & 1.05 & 1.01 & 1.00 \\
\hline
\end{tabular}

increases. Figure 7 shows the water retention curve obtained by the drainage/water-absorption process.

It is seen that the degree of saturation obtained under the same initial suction is similar to the value after the drainage/water-absorption process. The degree of saturation also decreases with an increase in the initial suction. The specimen data after the drainage/water-absorption tests are summarized in Table 3. It should be noted that the sample with zero suction was not saturated, i.e., from Tables 1 and 3, the saturation is $70 \%$ for the specimen with zero suction (U0-1).

\section{Drained Triaxial Compression Test Results}

The drained tests were conducted after the drainage/ absorption process, with the samples sheared under drained conditions for both the pore-air phase and the pore-water phase. During the shearing process, the specimens were compressed in the axial direction by applying the deviator stress, i.e., $\sigma_{1}-\sigma_{3}$, and by keeping the drainage valves for both pore air and pore water open. The pore-air pressure and the pore-water pressure were controlled at a constant pressure. Therefore, the initial

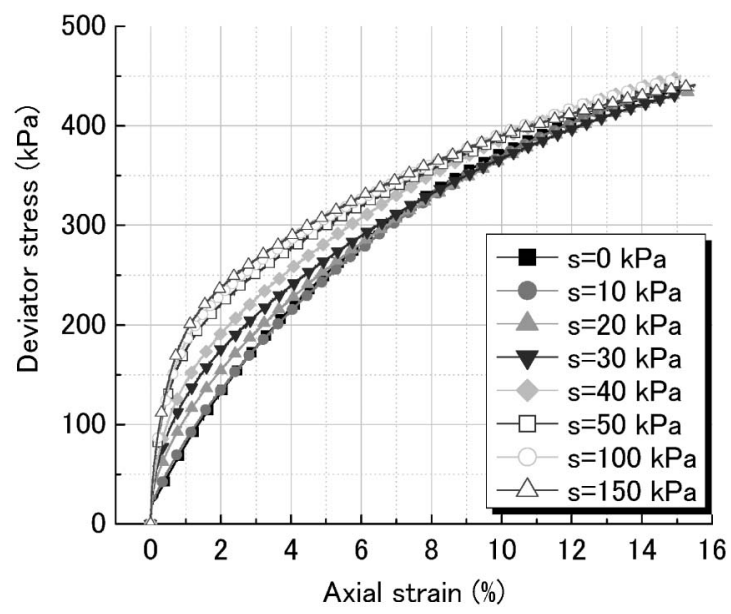

Fig. 8. Deviator stress-axial strain relations for specimens with different levels of initial suction under drained conditions

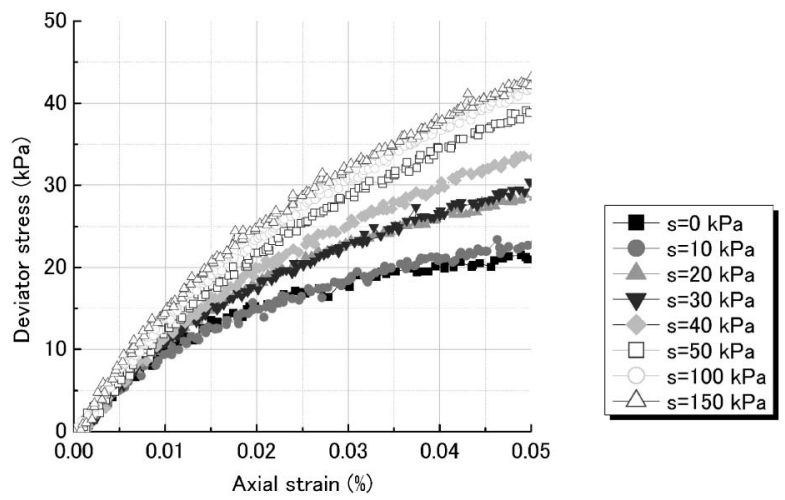

Fig. 9. Deviator stress-axial strain relations for specimens with different levels of initial suction under drained conditions (in the small strain range)

suction remained constant until failure conditions were reached, which was at $15 \%$ of the axial strain in this study.

In this section, the effects of the initial suction and the confining pressure under drained conditions will be described. Tests were carried out on samples D150-1, D100-1, D50-1, D40-1, D30-1, D20-1, and D10-1 (Table 1). The specimen data before the shearing tests are presented in Table 2.

1) Effect of the initial suction

The effect of the initial suction on the tests under drained conditions was investigated for Cases D150-1 D0-1. The drained tests were carried out with a constant stain rate of $0.05 \%$. Figures $8-12$ show comparisons among the results with initial suctions of $0,10,20$, $30,40,50,100$, and $150 \mathrm{kPa}$ under a constant confining pressure of $200 \mathrm{kPa}$.

The stress-strain relations under different suction levels are illustrated in Figs. 8 and 9. The results show an increase in the shear strength with an increase in the initial suction. The deviator stress for the samples with higher levels of initial suction is larger than that for the samples with lower levels of initial suction. The difference among 


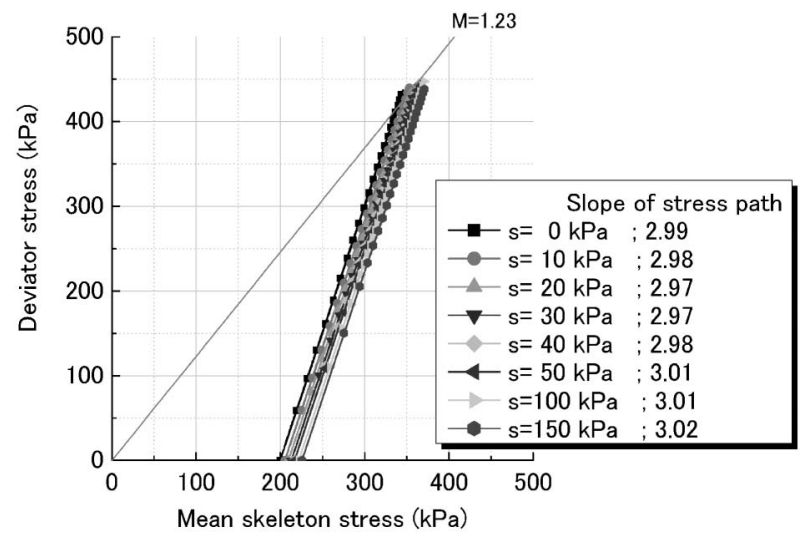

Fig. 10. Stress paths under drained conditions

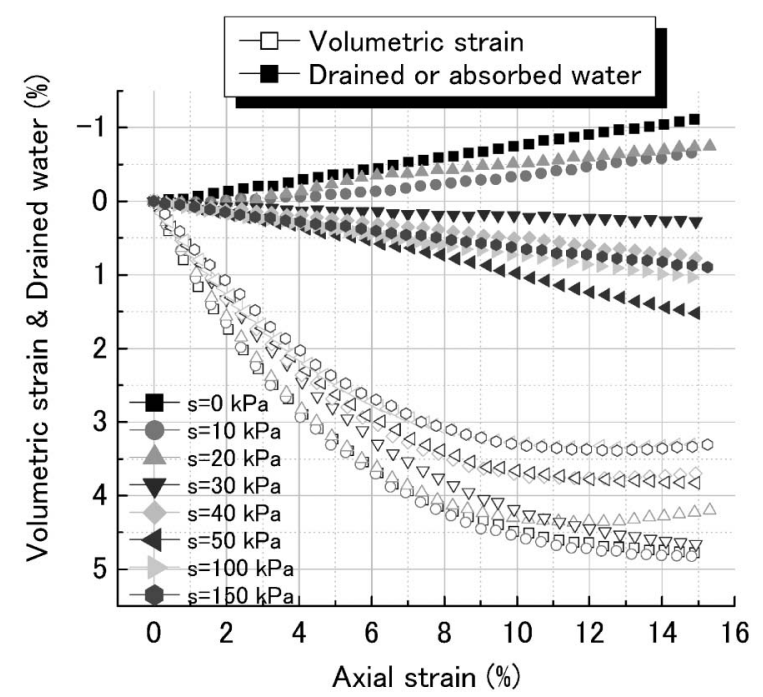

Fig. 11. Volumetric strain-axial strain relations and normalized-axial strain relations under drained conditions

the stress-strain curves becomes smaller as the strain increases in the range of an axial strain of $10-16 \%$.

As shown in the small strain range of Fig. 9, for an axial strain of about $0.05 \%$, the initial secant modulus with a suction of $150 \mathrm{kPa}$ is two times larger than that obtained with a suction of $0 \mathrm{kPa}$. On the other hand, the dependence of the initial modulus on the initial suction is not observed in the early stages of shearing.

Figure 10 illustrates stress paths in terms of the deviator stress and the mean skeleton stress. Since the mean skeleton stress is used, the slope of the stress paths is not 3.0 and the initial mean stress levels are not the same. Figure 11 shows the volumetric strain and the normalized drained water with respect to the initial value versus axial strain during shearing. For the volumetric strain, the soil specimen exhibits contractancy during shearing and the volume continuously decreases. The volume changes become small with an increase in the initial suction. In fact, the volume change curves are only valid up to an axial strain of $10 \%$ because of the limitations of the measurement method. It can be seen that the compressibility decreases when the initial suction increases.

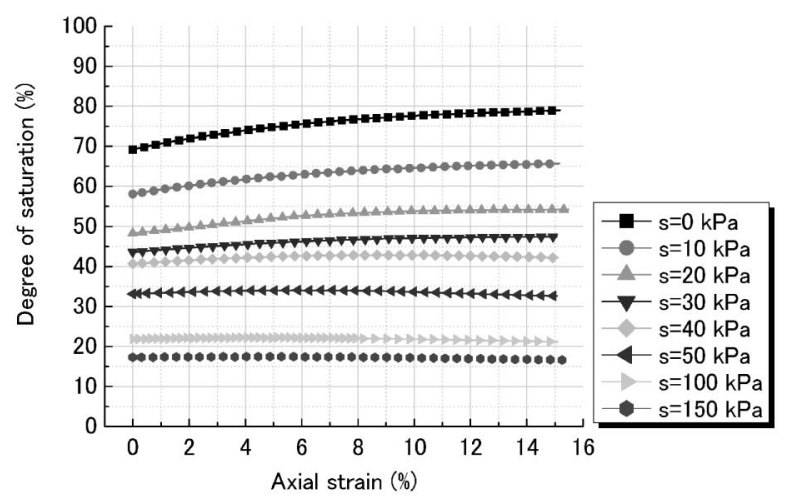

Fig. 12. Saturation-axial strain relations under drained conditions

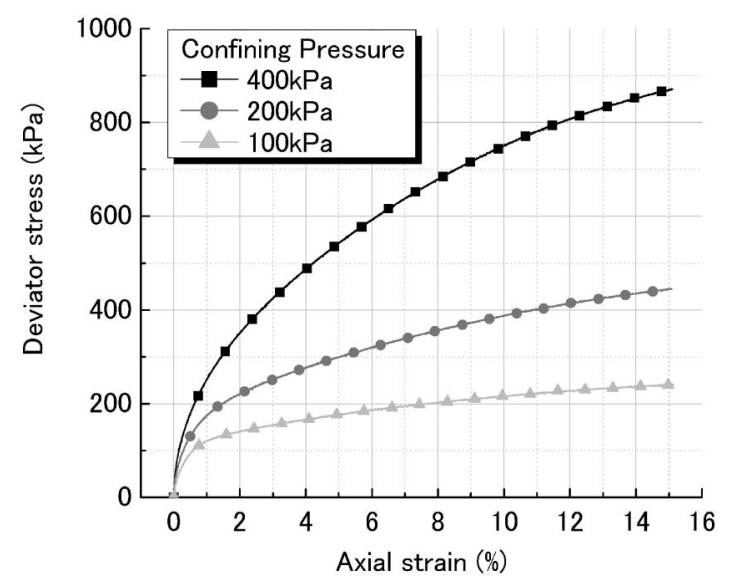

Fig. 13. Deviator stress-axial strain relations for different levels of confining pressure under drained conditions

During the shearing process, water drainage occurs with initial suctions of $30-150 \mathrm{kPa}$, whereas water absorption occurs with initial suctions of 0,10 and $20 \mathrm{kPa}$ while the volume change is compressive. As mentioned for the drainage/water-absorption process, this behavior is due to the fact that the initial suction is less than 20 $\mathrm{kPa}$, namely, the suction after the compaction of the sample.

Figure 12 shows the degree of saturation versus the axial strain during shearing. Suction increases slightly for the lower levels of initial suction, $0-20 \mathrm{kPa}$, while saturation is almost constant for the higher levels of suction.

2) Effect of the confining pressure

The effect of the confining pressure at a constant suction is illustrated in Figs. 13-17. The figures show a comparison among the results of cell pressure levels of 650 , 450 and $350 \mathrm{kPa}$ with an initial suction of $50 \mathrm{kPa}$ and a strain rate of $0.05 \% / \mathrm{min}$.

The stress-strain relations and the stress paths under different cell pressures are illustrated in Figs. 13 and 14 . The maximum deviator stress and the initial modulus increase with an increase in cell pressure for both large and small strain ranges. For the stress paths shown in Fig. 15, where the horizontal axis is the mean skeleton stress, the mean skeleton stress increases from its initial value. From 


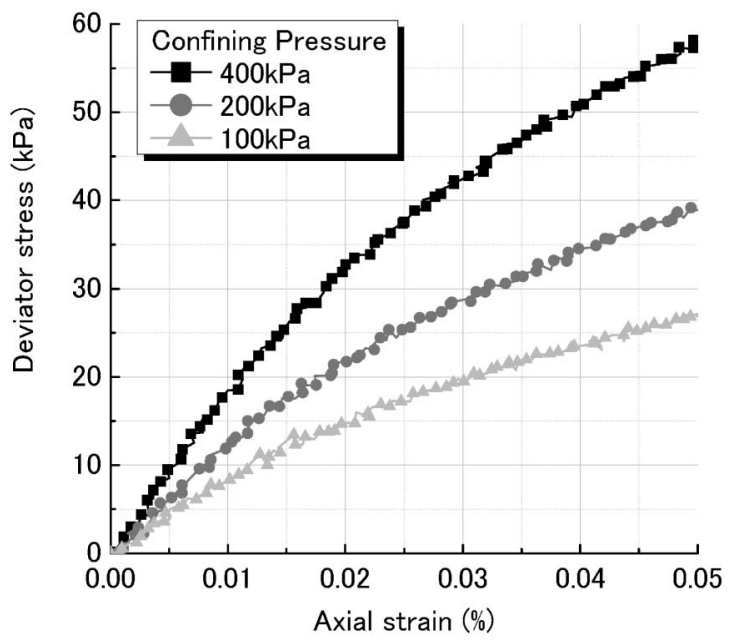

Fig. 14. Deviator stress-axial strain relations for different levels of confining pressure under drained conditions (in the small strain range)

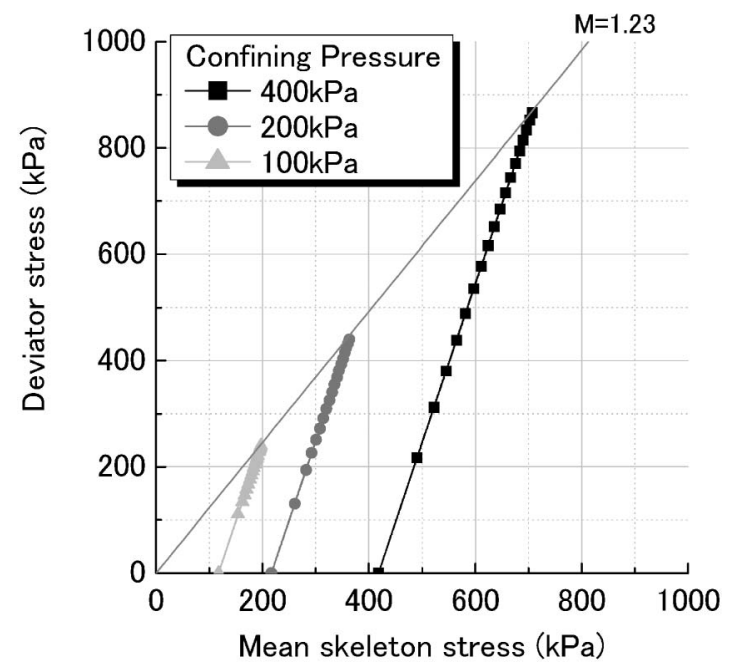

Fig. 15. Stress paths for different levels of confining pressure under drained conditions

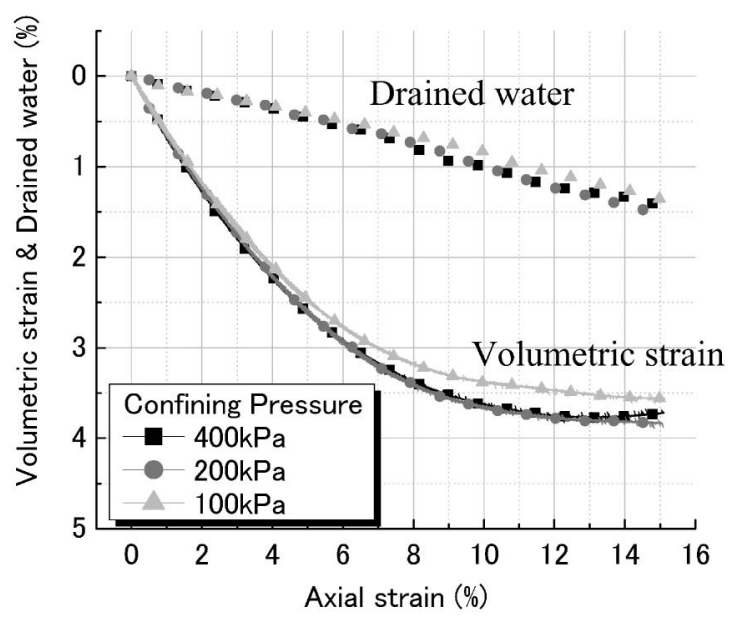

Fig. 16. Volumetric stain-axial strain relations for different levels of confining pressure under drained conditions

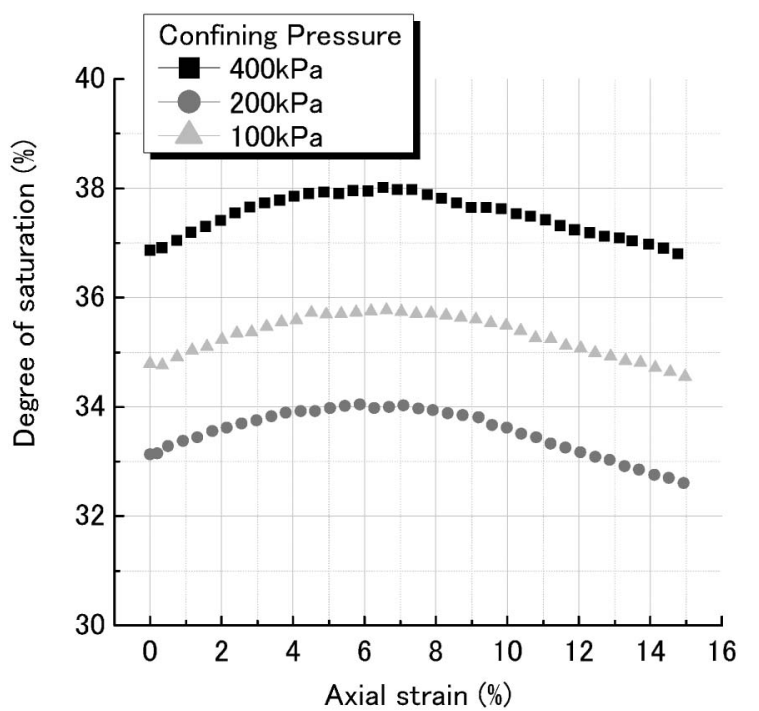

Fig. 17. Saturation-axial strain relations for different levels of confining pressure under drained conditions

Fig. 15, it is seen that the final points of the stress paths all meet at a straight line with a gradient of 1.23 that passes through the origin. Figure 16 shows the volumetric strain and the normalized drained water versus the axial strain. The effect of the cell pressure is not clear for the volume changes and drained water. Figure 17 illustrates the changes in saturation during the tests for different levels of confining pressure. The trend of the changes in saturation is similar in all cases and is not significantly influenced by the confining pressure.

\section{Fully Undrained Triaxial Compression Test Results}

Many laboratory tests have been conducted on unsaturated soil under a constant air pressure. However, the drained conditions for water and air cannot always be attained in engineering problems. For example, the air pressure in river embankments increases during the seepage process (Yamamura, 1971) and it may also vary during soil compaction. Since, in general, the air pressure changes under partially drained conditions, constantwater and constant-air content tests (on the constant gravimetric water and air content, e.g., Wulfsohn, Adams and Fredlund, 1998) need to be carried out in order to accurately describe the behavior of unsaturated soil under general boundary conditions. In the present paper, we have conducted triaxial tests on silty clay under fully undrained conditions for water and air.

In order to confirm that no leakage of air has occurred through the measuring lines, the pore pressure was measured under fully undrained conditions with the isotropic cell pressure for the specimen with a suction of $50 \mathrm{kPa}$. In the tests, the cell pressure was $450 \mathrm{kPa}$, and the pore-air pressure and the pore-water pressure just before shutting off the valves were $250 \mathrm{kPa}$ and $200 \mathrm{kPa}$, respectively. Figures 18 and 19 indicate the changes in volume and in the pore-air pressure and the pore-water pressure, respectively. From these figures, it is seen that the volume 


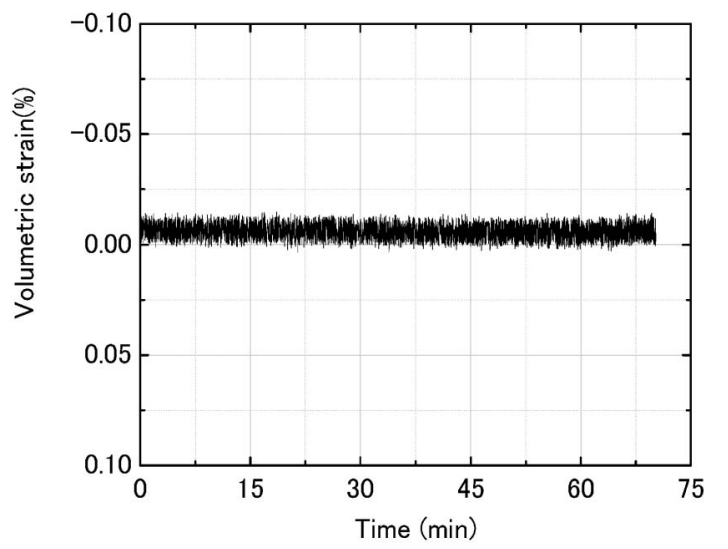

Fig. 18. Volumetric strain-time profile under fully undrained conditions during the application of isotropic stress

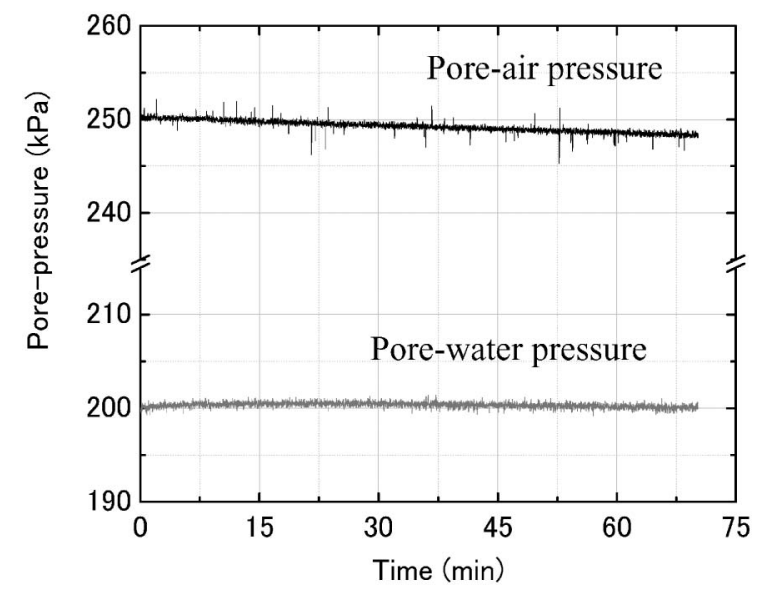

Fig. 19. Pore-air and pore-water profiles under fully undrained conditions during the application of isotropic stress

change was almost zero, the pore-water pressure was constant, and the pore-air pressure decreased slightly, by just $0.5 \mathrm{kPa}$ after $15 \mathrm{~min}$, and then decreased by $1.5 \mathrm{kPa}$ after $60 \mathrm{~min}$. This is due to the dissolution of the air into the pore water and not to the leakage of air. If any leakage of air had occured, the air pressure would have increased. This means that fully undrained conditions were successfully satisfied. Since the strain rate was set to $0.5 \% / \mathrm{min}$ in the following tests, and it takes $30 \mathrm{~min}$ for the axial strain to reach a strain of $15 \%$, the possible change in air pressure due to the solution was around $0.5 \mathrm{kPa}$ and could be considered negligible. From the above-mentioned data, we set the strain rate to be $0.5 \% / \mathrm{min}$ for the fully undrained tests, and then carried out the tests at strain rates of $0.05 \% / \mathrm{min}$ and $0.75 \% / \mathrm{min}$. Due to the limitations of the apparatus, the maximum strain rate was $0.75 \% / \mathrm{min}$.

In this section, the behavior of the pore pressure and the suction during the shearing process are described. Furthermore, the effects of the strain rate, the initial suction, and the confining pressure under fully undrained conditions will be discussed.

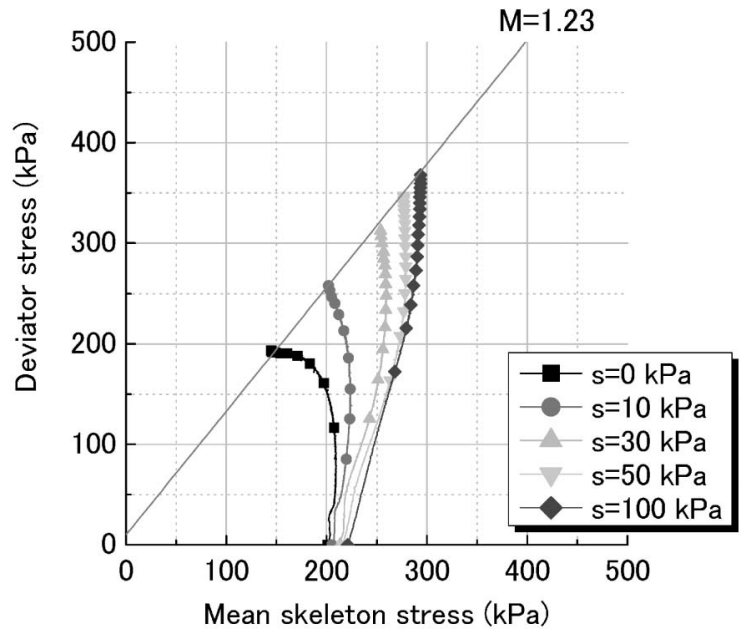

Fig. 20. Stress paths for specimens with different levels of initial suction under fully undrained conditions

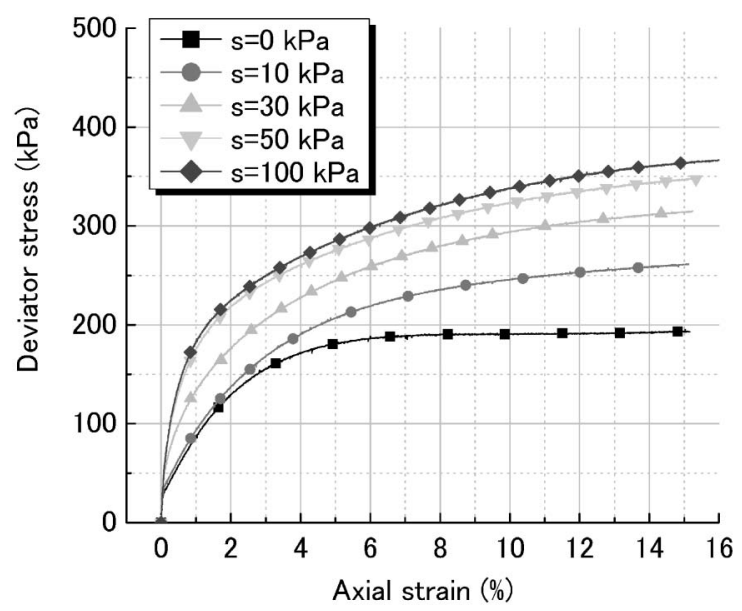

Fig. 21. Deviator stress-axial strain relations for specimens with different levels of initial suction under fully undrained conditions

1) Effect of the initial suction

In order to study the effect of the initial suction on the fully undrained tests, we carried out tests for specimens with various levels of suction, namely, $0,10,30,50$ and $100 \mathrm{kPa}$ with a confining pressure of $200 \mathrm{kPa}$ and a strain rate of $0.5 \% / \mathrm{min}$. All of the tests were conducted under fully undrained conditions and under a constant cell pressure of $450 \mathrm{kPa}$. From the stress paths shown in Fig. 20, it is seen that the decrease in the mean skeleton stress for the same deviator stress level was smaller with higher levels of suction and that the maximum deviator stress became larger for specimens with higher levels of initial suction. When the initial suction was at 0 and $10 \mathrm{kPa}$, the mean skeleton stress decreased and was less than the initial stress. As seen in this figure, the final points meet on a straight line with a gradient of 1.23 and an intercept of 8 $\mathrm{kPa}$. The stress-strain relations shown in Fig. 21 indicate that the deviator stress at the same axial strain is larger with higher levels of initial suction. From Fig. 22, it is seen that as the initial suction becomes higher, so does the 


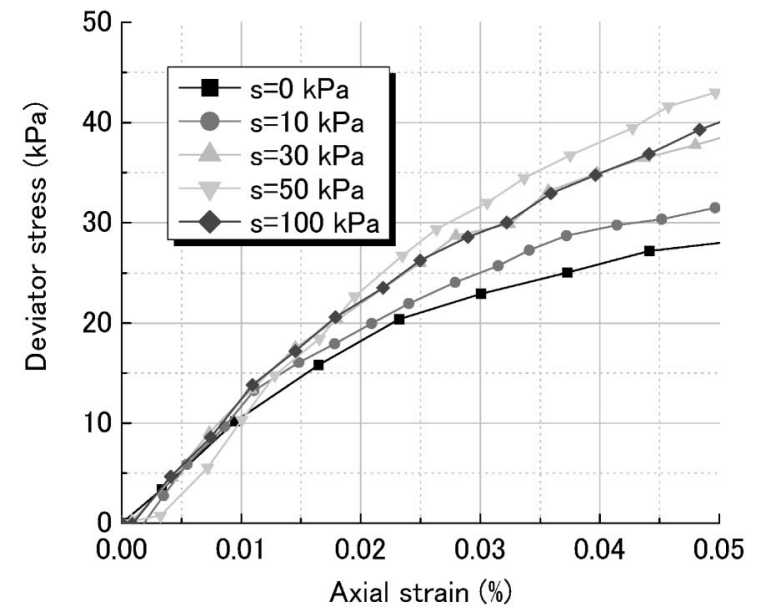

Fig. 22. Deviator stress-axial strain relations for specimens with different levels of initial suction under fully undrained conditions (in the small strain range)

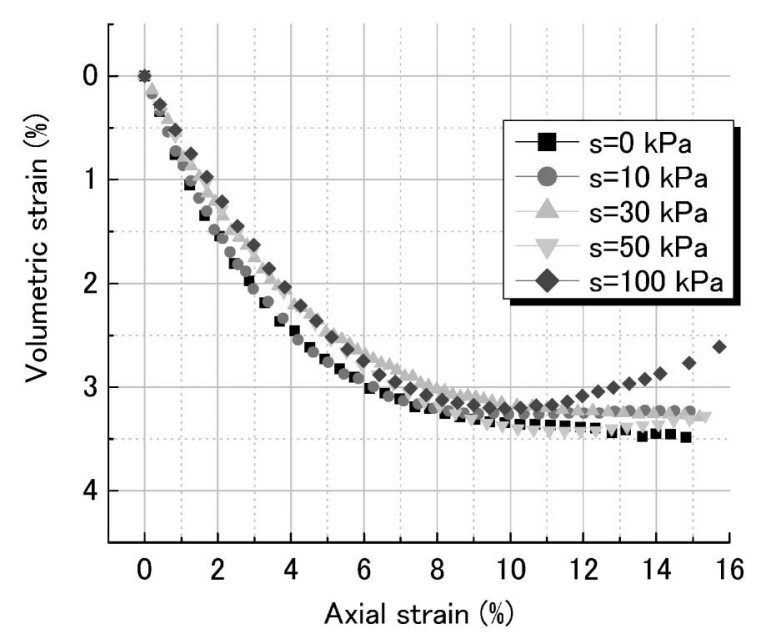

Fig. 23. Volumetric strain-axial strain relations for specimens with different levels of initial suction under fully undrained conditions

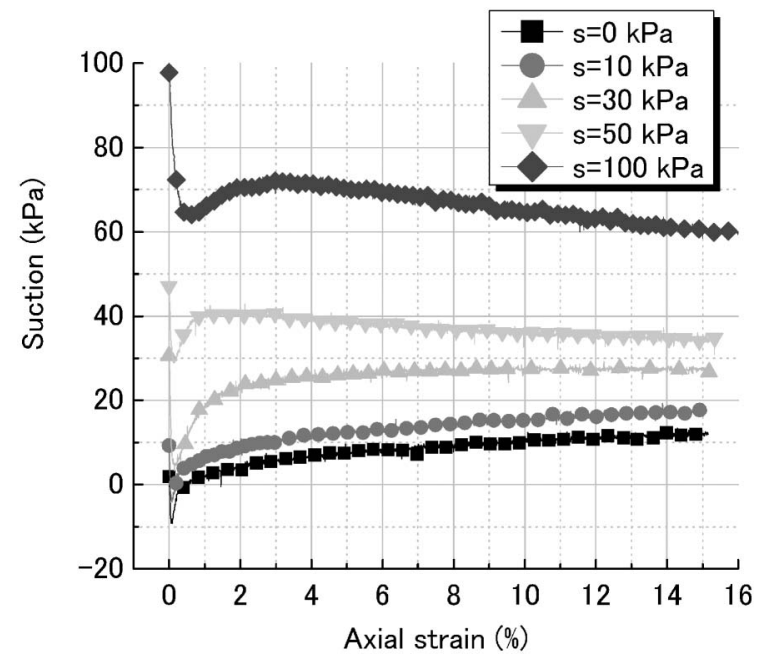

Fig. 24. Suction-axial strain relations for specimens with different levels of initial suction under fully undrained conditions

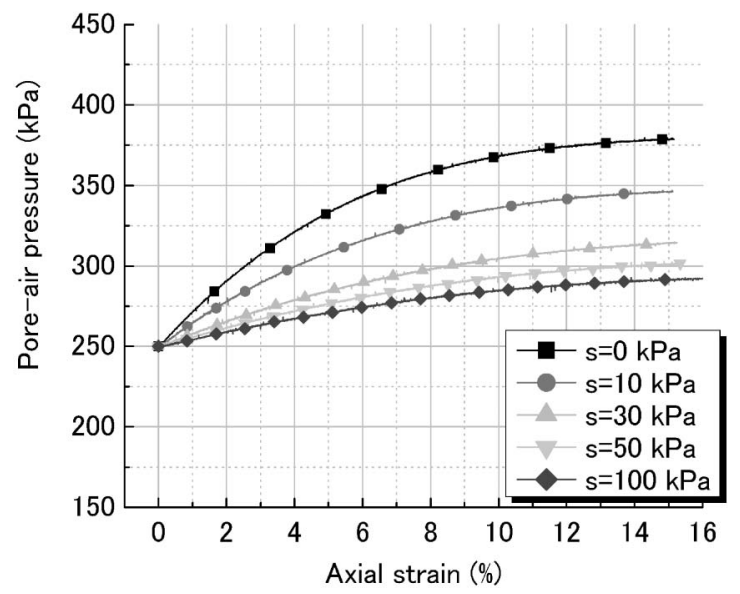

Fig. 25. Pore-air pressure-axial strain relations for specimens with different levels of initial suction under fully undrained conditions

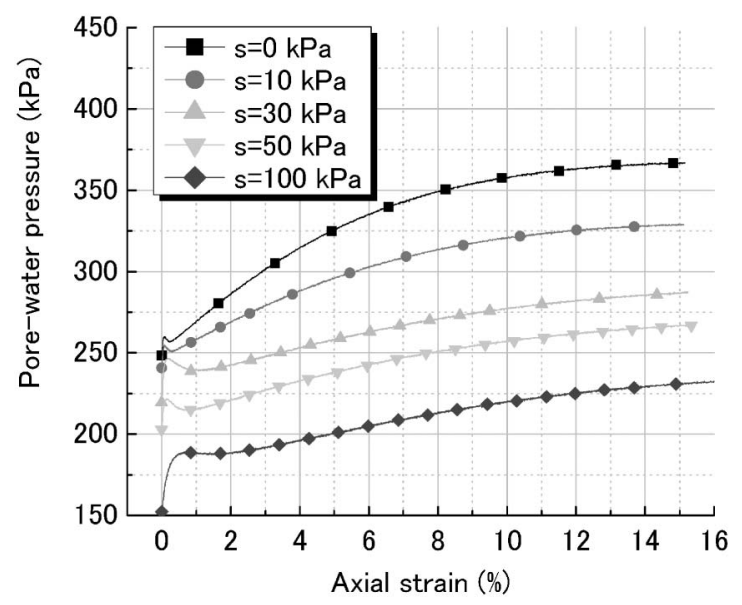

Fig. 26. Pore-water pressure-axial strain relations for specimens with different levels of initial suction under fully undrained conditions

initial modulus in the axial strain range between 0.0 and $0.04 \%$. Figure 23 illustrates the volumetric strain-axial strain relations. It is seen that at the same axial strain, a higher suction results in a smaller volumetric strain. In the case of a suction of $100 \mathrm{kPa}$, the volumetric strain increases and then decreases after reaching an axial strain of $10 \%$. This is due to incline of the target of the gap sensor for measuring the volumetric strain after the deformation of the specimen. The plot of the suction against the axial strain in Fig. 24 shows that suction immediately decreased, then increased, and finally for the lower levels of initial suction, namely, 0,10 , and $30 \mathrm{kPa}$, the suction gradually increased to a constant value. For the higher levels of initial suction, namely, 50 and $100 \mathrm{kPa}$, however, the suction decreased slightly and then became almost constant.

Figures 25 and 26 show the changes in pore-air pressure and pore-water pressure, respectively, during the tests. It is seen that the air pressure increased monotonically, but that the water pressure increased extensively in the range of small strain. The extensive decrease in suction in the early stages of straining was caused by the extensive in- 


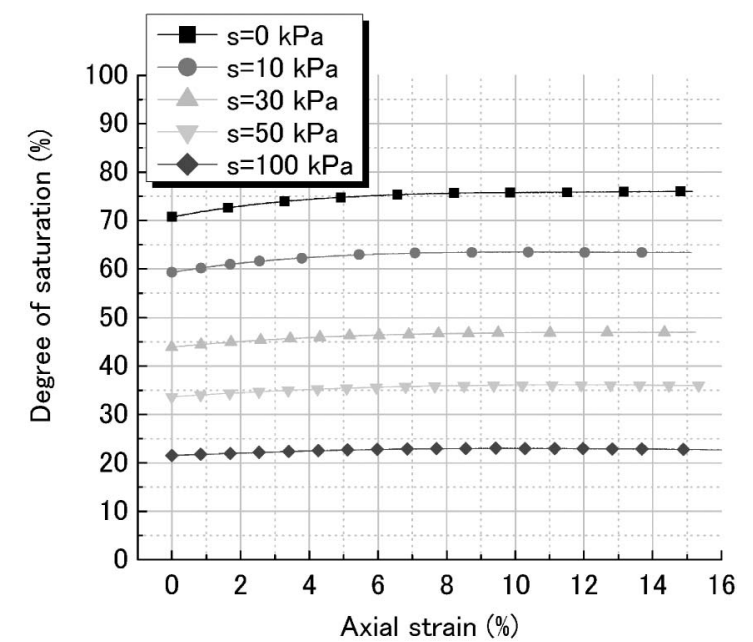

Fig. 27. Saturation-axial strain relations for specimens with different levels of initial suction under fully undrained conditions

crease in pore-water pressure. This behavior is associated with the great change in volume just after the start of the shearing because of the collapse of the loose structure of the soil specimen. From Fig. 25, it is seen that a lower suction (greater saturation) will generate a high level of pore-air pressure at the same level of axial strain. This can be explained as follows. Since the volume of air in the specimen is smaller for the case of higher levels of saturation and the changes in volume of the soil skeleton are almost the same for all cases, the air is compressed largely and the air pressure becomes high. Figure 27 indicates the saturation-axial strain profile in which the saturation increases in all cases and then becomes constant.

The stress conditions and the specimen data before the shearing tests are presented in Table 2; those after the tests are presented in Table 3 .

2) Effect of the strain rate

The effect of the stain rate is well known for various soil materials; it is particularly significant for clayey materials. Before investigating the stain rate effect for unsaturated silt, we performed undrained tests for saturated DL clay with different strain rates at a constant confining pressure of $200 \mathrm{kPa}$. Figures 28 and 29 illustrate the stress paths and stress-strain relations under undrained saturated conditions. The stress-strain responses are similar to those of loose sand (e.g., Ishihara, 1993). From these figures, the deviator stress for the case with a strain rate of $0.5 \% / \mathrm{min}$ is larger than that for the lower strain rate of $0.05 \% / \mathrm{min}$ in the axial strain range less than 1.37 $\%$. In contrast, in the larger strain range, the deviator stress for the case with a lower strain rate of $0.05 \% / \mathrm{min}$ is larger than that for the case with a higher strain rate of $0.5 \% / \mathrm{min}$. In the very small strain range where the axial strain is less than $0.05 \%$, the strain rate effect is clear and it is similar to that of the clayey soil shown in Fig. 30. An opposite trend of the strain rate effect is seen for the large strain due to the unstable structural change in the loose granular material and the viscoelastic nature of pore air.

To investigate the strain rate effect, we have carried out

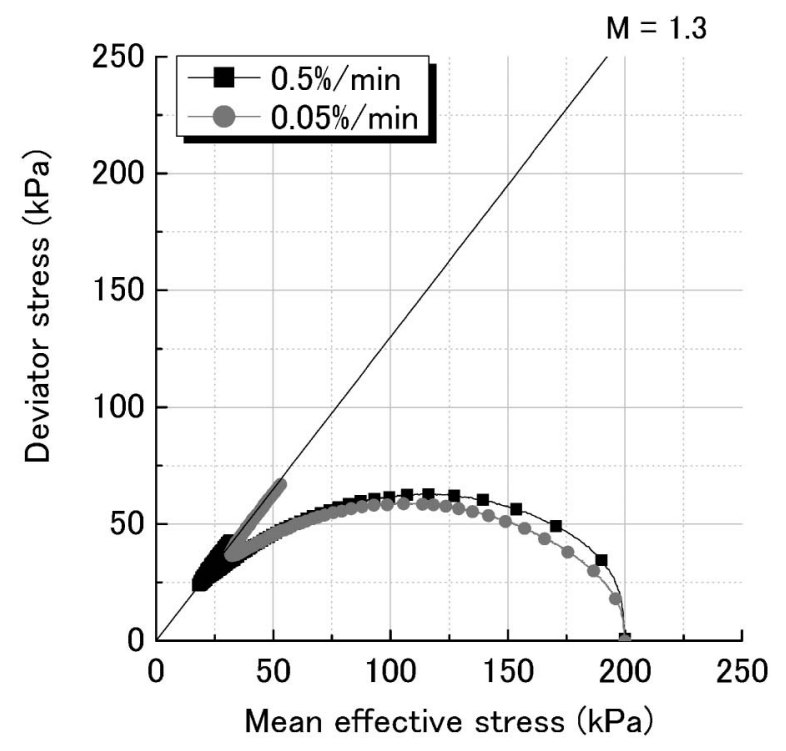

Fig. 28. Stress paths for saturated specimens under undrained conditions

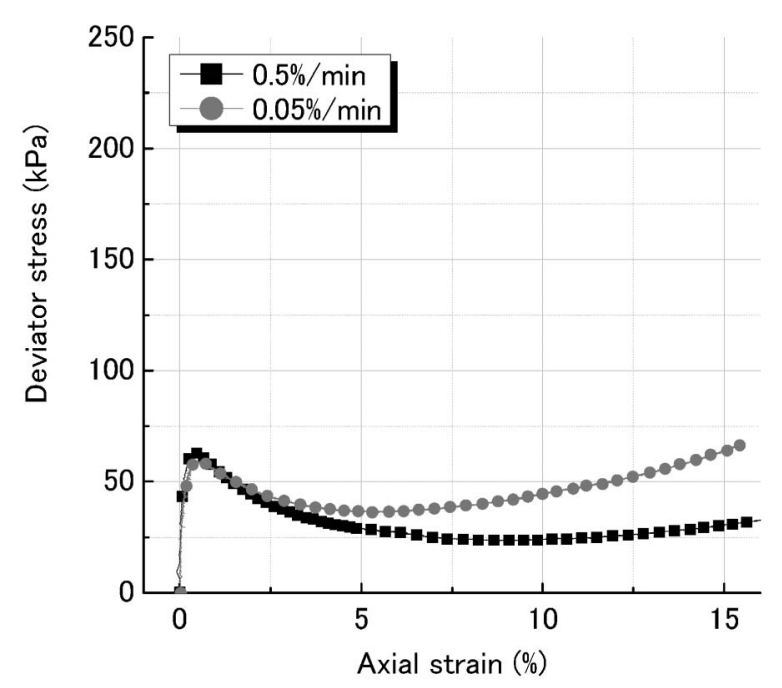

Fig. 29. Deviator stress-axial strain relations for saturated specimens under undrained conditions

fully undrained triaxial compression tests with three different axial strain rates, i.e., $0.75 \% / \mathrm{min}, 0.5 \% / \mathrm{min}$ and $0.05 \% / \mathrm{min}$ at a constant initial suction. Figures 31 and 32 indicate the stress paths and the stress-strain relations, respectively. The deviator stress for the case with the smallest strain rate $(0.05 \% / \mathrm{min})$ is larger than that for the larger strain rates $(0.5 \% / \mathrm{min}$ and $0.75 \% / \mathrm{min})$, and the decrease in the mean skeleton stress at the peak stress for the smallest strain rate of $0.05 \% / \mathrm{min}$ is smaller than that for the other two strain rates. The stress ratio at failure is about 1.27 which is very close to the value 1.23 for both drained and fully undrained conditions shown in Figs. 15 and 20.

In Fig. 33, for three different strain rates, the development of the compressive volumetric strain is similar at less than $8 \%$ of the axial strain. The difference in the 


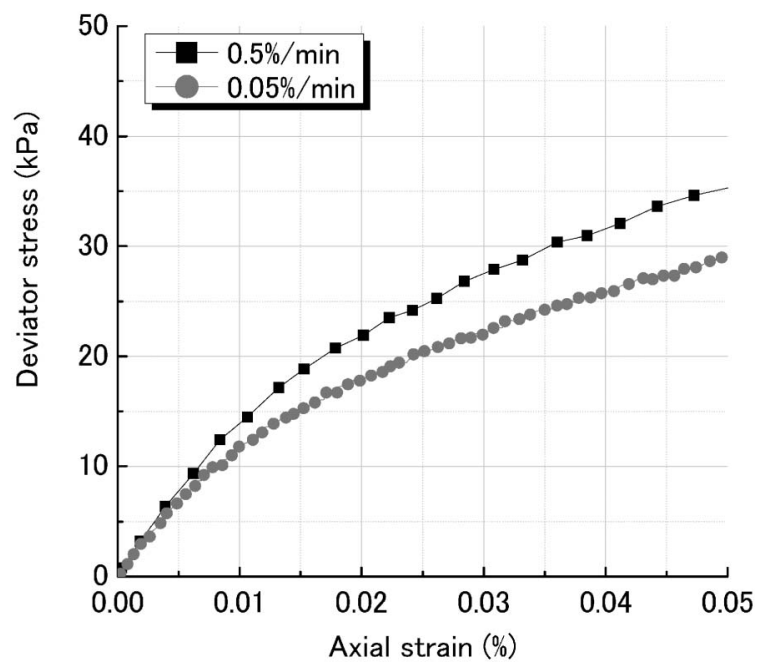

Fig. 30. Deviator stress-axial strain relations for saturated specimens under undrained conditions (in the small strain range)

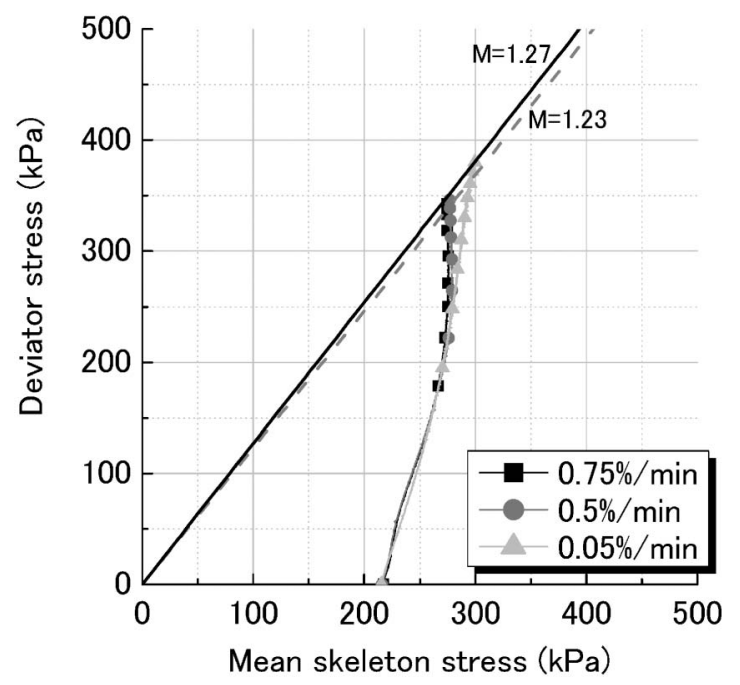

Fig. 31. Stress paths for specimens with different strain rates under fully undrained conditions

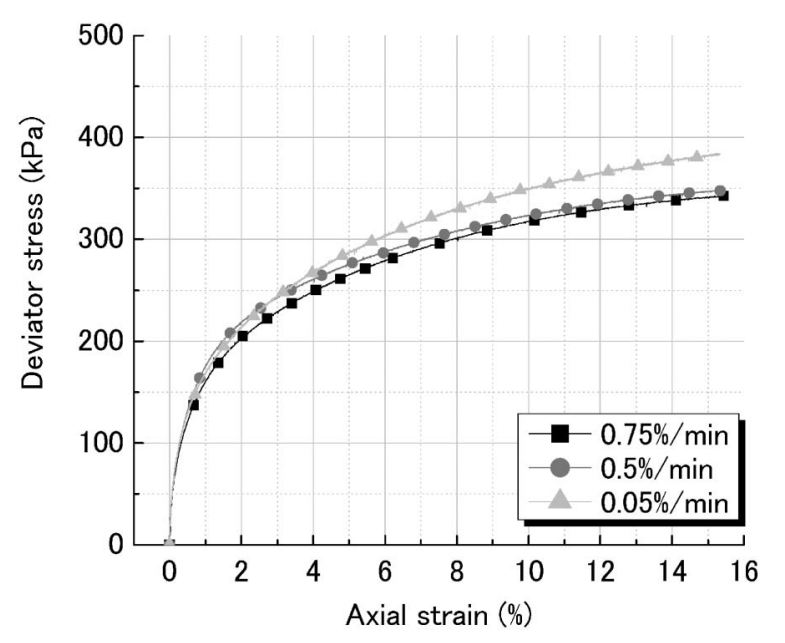

Fig. 32. Deviator stress-axial strain relations for specimens with different strain rates under fully undrained conditions

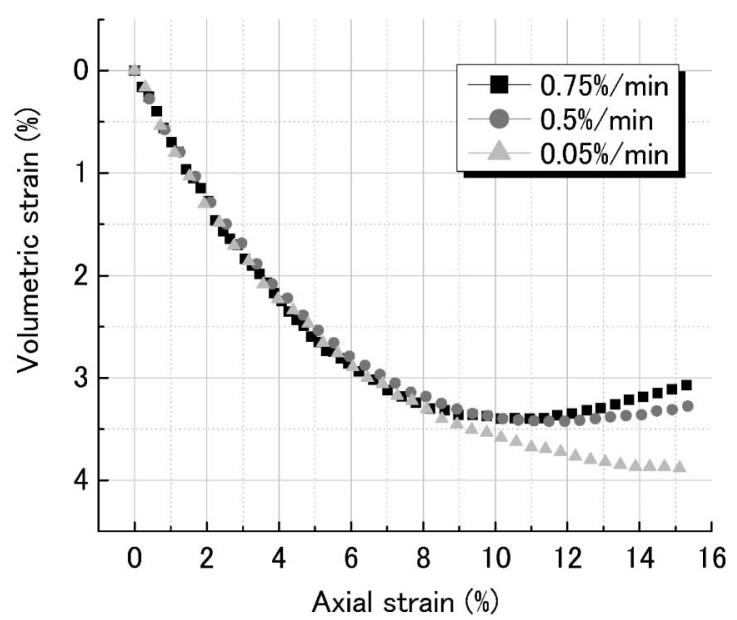

Fig. 33. Volumetric strain-axial strain relations for specimens with different strain rates under fully undrained conditions

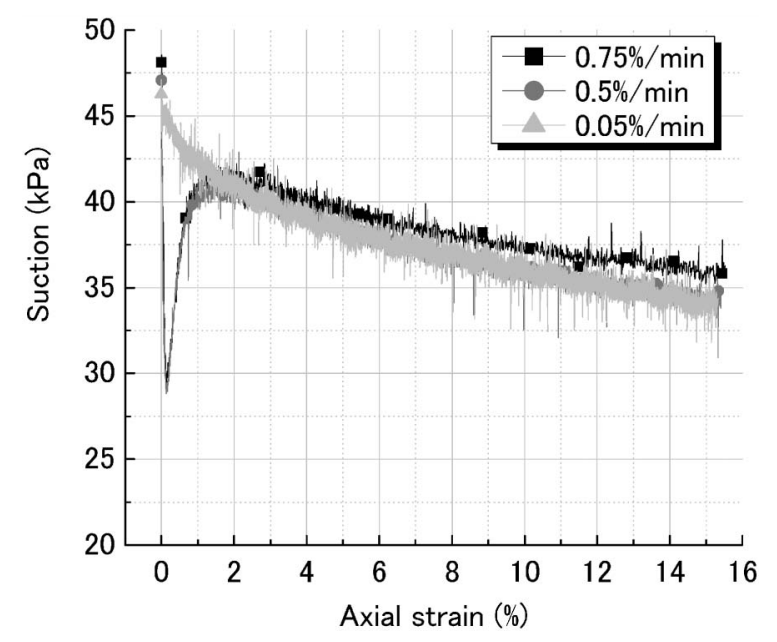

Fig. 34. Suction-axial strain relations for specimens with different strain rates under fully undrained conditions

changes in suction for the three strain rates is not as large as that indicated in Fig. 34, except during the early stages of loading. The average pore pressure, which is estimated from the pore-air and the pore-water responses shown in Figs. 35 and 36, respectively, indicates larger values for higher strain rates. There are three reasons for the larger average pore pressure that develops in the case of larger strain rates. The first reason is the dissolution of the pore air into the pore water; the reduction in pore-air pressure is $0.5 \mathrm{kPa}$ up to an axial strain of $15 \%$ for the strain rate of $0.5 \% / \mathrm{min}$, as shown in Fig. 19. Accordingly, if we assume that the dissolution is proportional to the time, the reduction in air pressure for a strain rate of $0.05 \%$ can be estimated at $5 \mathrm{kPa}$ up to an axial strain of $15 \%$. However, the difference in pore-air pressure between the two strain rates shown in Fig. 35 is more than $5 \mathrm{kPa}$. The second reason is the hardening of the soil skeleton due to the changes in the larger compressive volume during the longer loading time for the smallest strain rate, namely, $0.05 \% / \mathrm{min}$, indicated in Fig. 33. The third possible rea- 


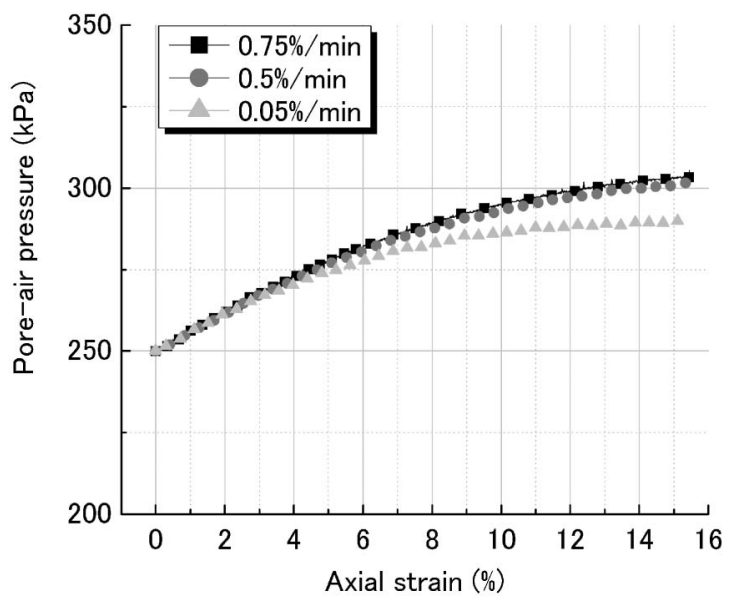

Fig. 35. Pore-air pressure-axial strain relations for specimens with different strain rates under fully undrained conditions

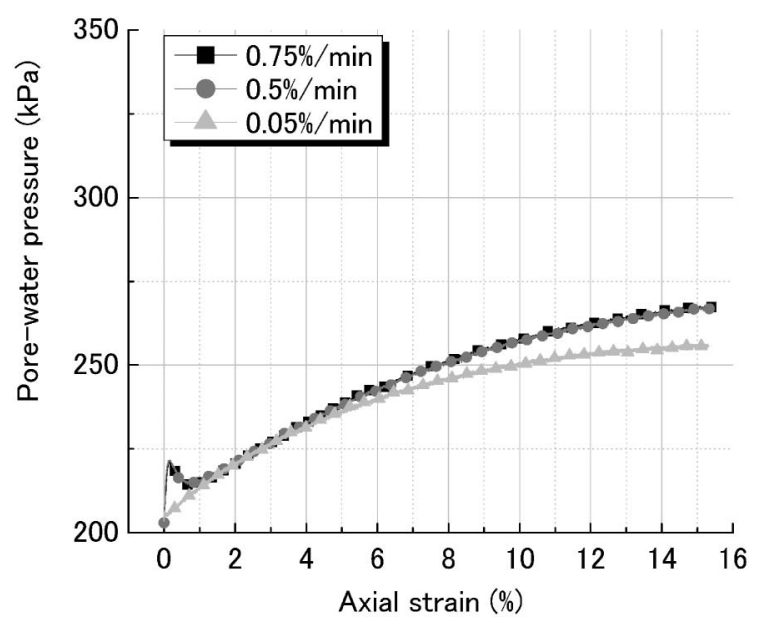

Fig. 36. Pore-water pressure-axial strain relations for specimens with different strain rates under fully undrained conditions

son may be the viscosity of the pore fluids. It should be pointed out that the possible dissolution of the air into the pore water leads to an increase in saturation and a decrease in suction, while Fig. 34 shows that the decrease in suction is similar for all three cases. For this type of test on unsaturated soil, the effect of the strain rate is more complex when compared to saturated soil (e.g., Adachi and Oka, 1982); it depends on the dissolution of the pore air, the changes in volume, and the viscous response of the pore fluids. It is worth noting that the peak strength envelope given by the straight line with a gradient of $1.23(M=1.23)$ and the intercept of $8 \mathrm{kPa}$ in Fig. 20 is consistent with that given in Fig. 31 .

3) Effect of the confining pressure

The effect of the confining pressure at an initial suction of $50 \mathrm{kPa}$ was observed from the tests with cell pressure levels of $450 \mathrm{kPa}$ and $350 \mathrm{kPa}$. Figures 37-39 show comparisons of the results obtained from cell pressures levels of $450 \mathrm{kPa}$ and $350 \mathrm{kPa}$ under fully undrained conditions. Since the initial air pressure was $250 \mathrm{kPa}$, the initial confining pressure levels were $200 \mathrm{kPa}$ and $100 \mathrm{kPa}$.

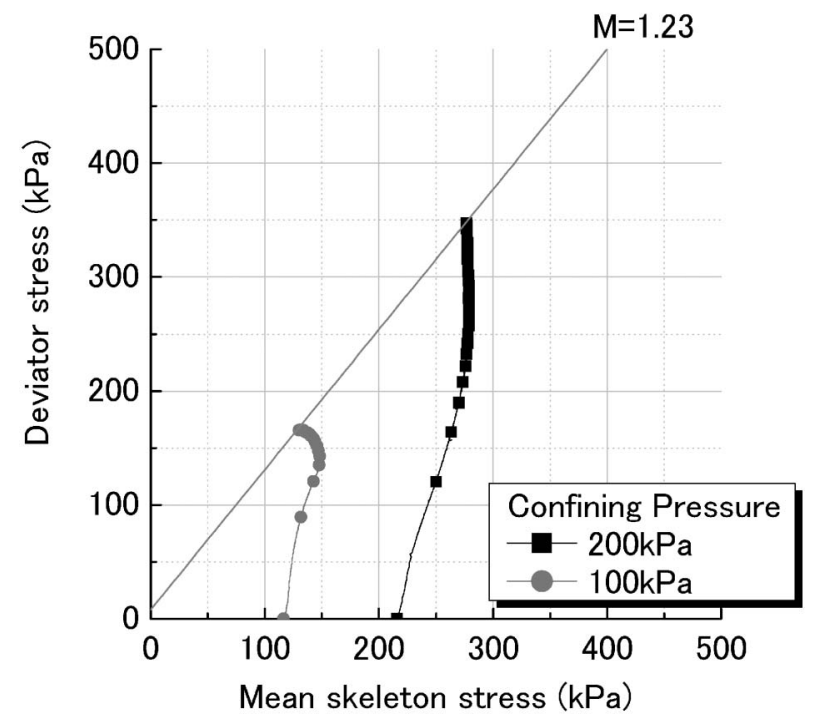

Fig. 37. Stress paths for different levels of confining pressure under fully undrained conditions

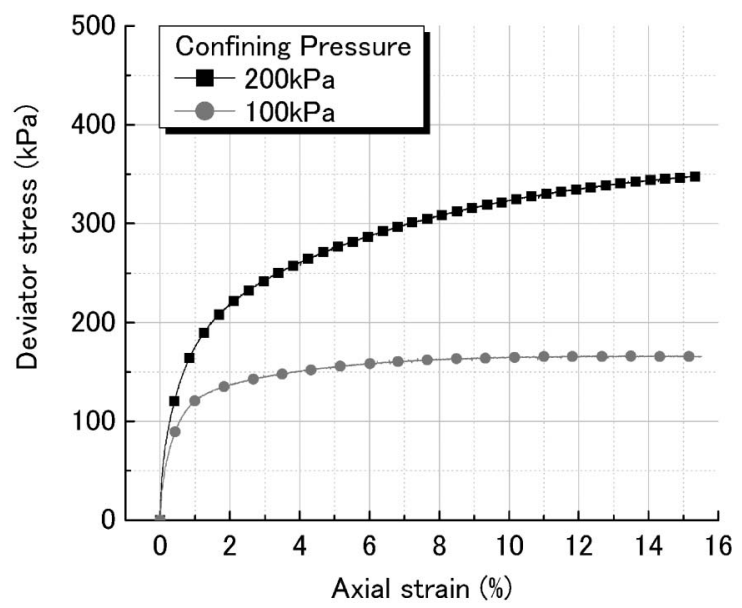

Fig. 38. Deviator stress-axial strain relations for different levels of confining pressure under fully undrained conditions

Figure 37 shows the stress paths. For the case with a confining pressure of $200 \mathrm{kPa}$, the mean skeleton stress increased monotonically with an increase in the deviator stress. For the case with a confining pressure of $100 \mathrm{kPa}$, however, the mean skeleton stress increased and then decreased after the deviator stress reached $140 \mathrm{kPa}$. It appears that the peak stress falls on the straight line with a gradient of 1.23 and an intercept of $8 \mathrm{kPa}$. The stressstrain relations shown in Fig. 38 indicate that a higher confining pressure brings about a larger deviator stress. For the volumetric strain shown in Fig. 39, a large volumetric strain is observed at the same axial strain for the higher confining pressure. With an axial strain in excess of $10 \%$, it was confirmed that the measurement of the volumetric strain is not reliable because of the inclination of the target of the gap sensor using the volume change of saturated soil (Kim, 2004).

The plot for the suction against the axial strain in Fig. 


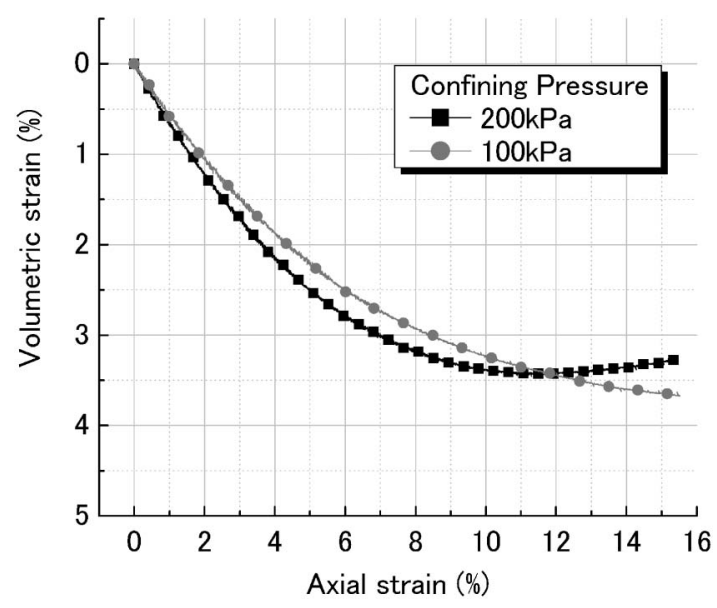

Fig. 39. Volumetric strain-axial strain and normalized drained wateraxial strain relations for different levels of confining pressure under fully undrained conditions

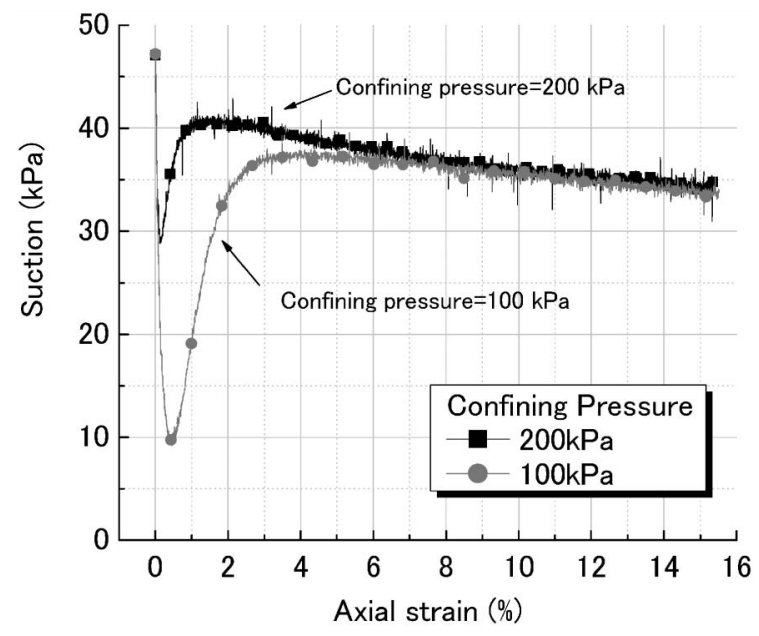

Fig. 40. Suction-axial strain relations for different levels of confining pressure under fully undrained conditions

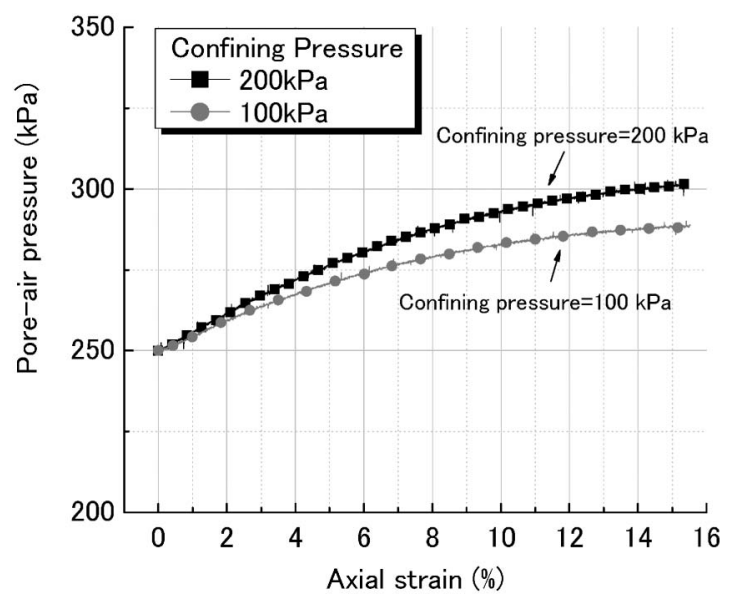

Fig. 41. Pore-air pressure-axial strain relations for different levels of confining pressure under fully undrained conditions

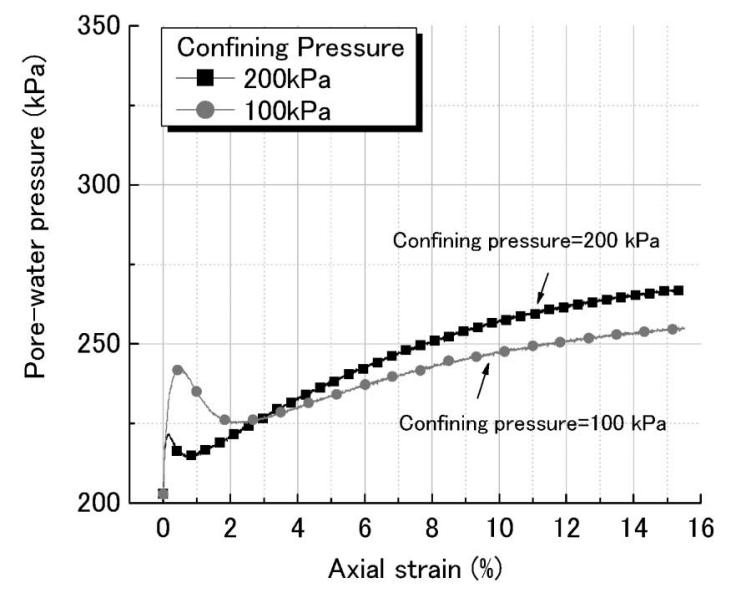

Fig. 42. Pore-water pressure-axial strain relations for different levels of confining pressure under fully undrained conditions

40 indicates that the magnitude of the extensive decrease in suction was larger for the lower levels of confining pressure. Figures 41 and 42 show the changes in pore-air pressure and pore-water pressure, respectively, against the axial strain. An increase in pore-air pressure was observed for higher levels of confining pressure. For changes in pore-water pressure, the extensive increase in pore-water pressure at the small strain level was larger for the lowest level of confining pressure. The final porewater pressure was higher for the higher levels of confining pressure.

\section{DISCUSSIONS}

As shown in Fig. 8, the stress-strain relations obtained from the drained tests indicate that the deviator stress for the higher levels of initial suction is larger than that for the lower levels of initial suction in the early stages of straining, while the stress reaches almost the same value with an increase in strain. The stress-strain relations by the fully undrained tests, shown in Fig. 21, produce a similar trend, but the results are different, namely, the shear strength with the highest initial suction is quite a bit larger than that with the smallest initial suction. The effect of the initial suction on the stress-strain relation in the fully undrained tests is more significant than that obtained from the drained tests.

The stress paths obtained from the fully undrained tests in Fig. 20 show a decrease in the mean skeleton stress for the lower levels of initial suction. This explains the strong dependence of the shear strength on the initial suction in the above-mentioned fully undrained tests.

Next we will discuss the development of volumetric strain during both the drained and the fully undrained tests. The volume change feature of the drained tests in Fig. 11 is clear; a higher initial suction brings about a smaller volume change. This trend for the undrained tests is similar to the trend for the drained tests. By looking at the details of the results in Fig. 23, however, it can be seen that the initial suction dependency of the volumetric strain is not simple. For example, the development of 
volumetric strain in the case of an initial suction of 50 $\mathrm{kPa}$ is larger than that for an initial suction of $30 \mathrm{kPa}$. This might be due to that the dependence of the volume change on both the compressibility of the soil skeleton and the volume of pore air. The soil specimens with higher levels of initial suction contain a larger volume of pore air because of the low saturation.

During the fully undrained tests in Fig. 24, the suction immediately drops and then increases for cases with a lower initial suction or decreases for cases with a higher initial suction, and then finally reaches an almost constant value of suction. It is of interest to note that this trend is different from that of the undrained tests, i.e., the so-called constant water content test, in which the suction decreases monotonically because the pore-water pressure increases while the pore-air pressure is constant (e.g., Wulfsohn et al., 1998).

The effect of the stain rate on the behavior of the soil is important not only for saturated soil, but also for unsaturated soil. However, there have been very few studies on the effect of the strain rate on the behavior of soil for unsaturated soil, possibly because it is difficult to perform fully undrained tests, i.e., water-content constant and air-content constant tests, to study the time dependency separately from that due to the pore-fluid flow. The stress paths with higher strain rates indicate an opposite trend, i.e., for normally consolidated saturated clayey soil, the decrease in the mean effective stress is smaller for higher strain rates, while Fig. 31 shows that the decrease in the mean skeleton stress is lower for lower strain rates. This type of behavior is consistent with the development of the larger pore-water pressure and the larger pore-air pressure, i.e., a higher value for the average pore pressure.

From the stress-strain relations and the volume change characteristics of both the drained tests and the fully undrained test results shown in Figs. 8, 10, 11, 20, 21, and 23 , it has been shown that the critical state concept can be applied to the behavior of this silt considering the almost zero change in volume around the peak stress. From the stress paths by the deviator stress-mean skeleton stress plots in Figs. 10 and 15, the peak stress envelopes of the drained tests yield a gradient of 1.23 with a zero intercept. On the other hand, the peak stress envelopes of the fully undrained tests of Figs. 20, 31, and 37 provide a gradient of 1.23 and an intercept of $8 \mathrm{kPa}$ on the deviator stressmean skeleton stress plane. The same value for the gradients along the critical state line for all cases indicates that the behavior of the unsaturated specimen tests in the present study can be described well through the use of the skeleton stress expressed by Eq. (2), although the intercepts are different between the drained and the fully undrained tests. This is consistent with the implication of the generalized effective stress by Nuth and Laluoi (2008). They showed that the generalized effective stress is useful for uniquely describing the behavior of unsaturated soil. As mentioned previously, the form of the generalized effective stress is the same as that for the skeleton stress according to Eq. (2).

\section{CONCLUSIONS}

In this paper, two types of triaxial compression tests for unsaturated compacted silt with two different drainage conditions were conducted. One type consisted of tests under drained conditions and the second under fully undrained conditions in which the water content and the air content were constant. The fully undrained tests were performed using an air-controlled valve for measuring the pore-air pressure. The changes in volume of the specimens during the tests were measured with non-contacting transducers. The main conclusions obtained from the tests are as follows:

1) Water content and air content constant tests were carried out using an air-controlled valve in the air pressure measuring system. This type of test is called a fully undrained test. The fully undrained test results are useful for the modeling of unsaturated soil which can simulate the behavior of unsaturated soil during rapid loading, such as during earthquakes. The method using the non-contacting transducers generated a good estimation of the volume measurement.

2) During the isotropic drainage/water-absorption process, the gradient for the decreasing void ratio with the mean skeleton stress decreased with increased suction in the skeleton stress-void ratio plane. A clear decrease in compressibility was seen when the suction increased.

3) The results by the drained tests showed that the deviator stress for the samples with the higher levels of initial suction was larger than that with the lower levels of initial suction in the range in axial strain of $6-8 \%$. The difference between the stress-strain curves became less as the strain increased and reached an almost constant value.

4) In the fully undrained tests, the initial suction strongly affected the stress-strain response. The shear strength was larger for samples with higher levels of suction while the shear strength by the drained tests (that is, the shear stress at large levels of strain) were almost equal.

5) Under the fully undrained conditions, both the excess pore-air pressure and the excess pore-water pressure increased with increasing axial strain. The suction decreased extensively in the range of a small axial strain of less than $0.5 \%$ from the initial value and then the suction increased for lower levels of initial suction, while the suction for higher levels of initial suction increased and then slightly decreased for higher levels of initial suction.

6) The strain rate affected the stress-strain relations and the stress paths for the fully undrained tests. The maximum deviator stress for the case with higher strain rates was lower than those with lower strain rates. It seems that the strain rate effect comes from a combination of the viscoelastic property of the pore fluids and the loading time.

7) The stress ratio (the ratio of deviator stress over the mean skeleton stress) at large strain was almost in- 
dependent of the initial suction, the confining pressure, and the shearing conditions for the present experimental results. The stress ratio at failure or large strain obtained from all the cases, was around 1.23. This result indicates that the behavior during the unsaturated specimen tests in the present study can be described well through the use of the skeleton stress adopted in the present paper.

\section{LIST OF SYMBOLS}
$s$ : suction
$u_{\mathrm{a}}$ : pore-air pressure
$u_{\mathrm{w}}$ : pore-water pressure
$\sigma_{\mathrm{ij}}^{\prime}$ : skeleton stress
$S_{\mathrm{r}}$ : degree of saturation
$P^{F}$ : average pore pressure
$\varepsilon_{\mathrm{a}}$ : axial strain
$\varepsilon_{\mathrm{r}}$ : average lateral strain

\section{REFERENCES}

1) Adachi, T. and Oka, F. (1982): Constitutive equations for normally consolidated clay based on elasto-viscoplasticity, Soils and Foundations, 22(4), 57-70.

2) Aitchison, G. D. (1960): Relationships of moisture stress and effective stress functions in unsaturated soils, Proc. Conference Pore Pressure and Suction in Soils, London, British Nat. Soc. of ISSMFE, Butterworths, 47-52.

3) Alonso, E. E., Gens, A. and Josas, A. (1990): A constitutive model for partially saturated soils, Geotechnique, 40(3), 405-430.

4) Baumgartl, Th., Winkelmann, P., Graesle, W., Richards, B. G. and Horn, R. (1995): Measurement of the interaction of soil mechanical properties and hydraulic processes with a modified triaxial test, Proc. 1st Int. Conference on Unsaturated Soils, UN$S A T$ '95, Paris, France (eds. by Alonso, E. E. and Delage, P.), Balkema, 433-438.

5) Bishop, A. W. (1960): The measurement of pore pressure in the triaxial test, Proc. Conf. Pore Pressure and Suction in Soils, Butterworths, London, 38-46.

6) Bishop, A. W. and Donald, I. B. (1961): The experimental study of partly saturated soil in the triaxial apparatus, Proc. 5th ICSMFE, Paris, France, 1, 13-21.

7) Bishop, A. W. and Henkel, D. J. (1962): The Measurements of Soil Properties in the Triaxial Tests, Edward Arnold Publisher, 2nd edition, London.

8) Bolzon, G., Schrefler, B. A. and Zienkiewicz, O. C. (1996): Elastoplastic soil constitutive laws generalized to partially saturated states, Geotechnique, 46(2), 279-289.

9) Clayton, C. R. and Khatrush, S. A. (1986): A new device for measuring local strains on triaxial specimens, Geotechnique, 36(4), 593-597.

10) Cole, D. M. (1978): A technique for measuring radial deformation during repeated load triaxial testing, Canadian Geotechnical Journal, 15, 426-429.

11) Coleman, J. D. (1962): Stress/strain relations for partly saturated soil, Correspondence, Geotechnique, 12(4), 348-350.

12) Ehlers, W., Graf, T. and Ammann, M. (2004): Deformation and localization analysis of partially saturated soil, Compt. Methods Appl. Mech. Engrg., 193, 2885-2910.

13) Fredlund, D. G. and Morgenstern, N. R. (1977): Stress state variables for unsaturated soils, J. Geotech. Engng Div. Am. Soc. Civ. Engrs., 103(GT5), 313-321.

14) Gallipoli, D., Gens, A., Vaunat, J. and Romeo, E. (2002): Role of degree of saturation on the normally consolidated behavior of unsaturated soil, Proc. 3rd Int. Conf. Unsaturated Soils, Recife,
113-120, 2002.

15) Gallipoli, D., Gens, A., Sharama, R. and Vaunat, J. (2003): An elasto-plastic model for unsaturated soil incorporating the effects of suction and degree of saturation on mechanical behaviour, Geotechnique, 53(1), 123-135.

16) Houlsby, G. T. (1997): The work input to an unsaturated granular material, Geotechnique, 47(1), 193-196.

17) Ishihara, K. (1993): Liquefaction and flow failure during earthquakes, Geotechnique, 43(3), 351-415.

18) Jommi, C. (2000): Remarks on the constitutive modelling of unsaturated soils, Experimental Evidence and Theoretical Approaches in Unsaturated Soils (eds. by Tarantio, A. and Mancuso, C.), Balkema, 139-153.

19) Karube, D. and Kawai, K. (2001): The role of pore water in the mechanical behavior of unsaturated soils, Geotechnical and Geological Engineering, 19, 211-241.

20) Khan, A. H. and Hoag, D. L. (1979): A non-contacting transducer for measurement of lateral strains, Canadian Geotechnical Journal, 16, 409-411.

21) Kim, Y.-S. (2004): Elasto-viscoplastic modeling and analysis for cohesive soil considering suction and temperature effects, Doctoral Thesis, Kyoto University.

22) Kim, Y.-S., Kimoto, S., Oka, F. and Kodaka, T. (2005): Numerical simulation of the triaxial compression behaviour of unsaturated silt using an elasto-viscoplastic model, Proc. 11th IACMAG, Torino, Italy, 19-24, June 2005, 1361-1368.

23) Kimoto, S., Oka, F., Fujiwaki, M. and Fujita, Y. (2007): Numerical analysis of deformation of methane hydrate contained soil due to the dissociation of gas hydrate, Bifurcations, Instabilities, Degradation in Geomechanics (eds. by George E. Exadaktylos and Ioannis G. Vardoulakis), Springer, 361-380.

24) Kimoto, S., Oka, F., Fushita, T. and Fujiwaki, M. (2007): A chemo-thermo-mechanically coupled numerical simulation of the subsurface ground deformations due to methane hydrate dissociation, Computers and Geotechnics, 34(4), 216-228.

25) Kohgo, Y., Nakano, M. and Miyazaki, T. (1993): Theoretical aspects of constitutive elastoplastic model for unsaturated soils, Soils and Foundations, 33(4), 49-63.

26) Kolymbas, D. and Wu, W. (1989): A device for lateral strain measurements in triaxial tests with unsaturated specimens, Geotechnical Testing Journal, 12(3), 227-229.

27) Lo Presti, D. C. F., Pallara, O. and Puci, I. (1995): A modified commercial triaxial testing system for small strain measurements, preliminary results on Pisa clay, Geotechnical Testing Journal, 18(1), 15-31.

28) Loret, B. and Khalili, N. (2000): A three phase model for unsaturated soils, Int. J. Numer. Anal. Meth. Geomech., 24(11), 893-927.

29) Macari, E. J., Parker, J. K. and Costes, N. C. (1997): Measurement of volume changes in triaxial tests using digital imaging techniques, Geotechnical Testing Journal, 20(1), 103-109.

30) Matyas, E. L. (1967): Air and water permeability of compacted soils, American Society of Testing and Materials, ASTM STP 417, 160-175.

31) Nishimatsu, N. (2004): Experimental study of the suction effect on an unsaturated compacted silt, Master's Thesis, Kyoto University, Kyoto, Japan (in Japanese).

32) Nuth, M. and Laloui, L. (2008): Effective stress concept in unsaturated soil: Clarification and validation of a unified framework, Int. J. Num. Anal. Meth. Geomech., 32, 771-801.

33) Oka, F., Kodaka, T., Kimoto, S., Kim, Y. and Yamasaki, N. (2006): An elasto-viscoplastic model and multiphase coupled FE analysis for unsaturated soil, Unsaturated Soils Proc. 4th Int. Conf. Unsat. Soils, Carefree Arizona, 2-6 April 2006, ASCE, (2), 2039-2050.

34) Oka, F., Kodaka, T., Kimoto, S., Kim, Y.-S. and Yamasaki, N. (2006): A multi-phase coupled FE analysis using an elasto-viscoplastic model for unsaturated soil, Geomechanics II, Geotechnical Special Publication, ASCE, Proc. 2nd US-Japan Workshop on Geomechanics, 124-131.

35) Oka, F., Feng, H., Kimoto, S., Kodaka, T. and Suzuki, H. (2008): 
A numerical simulation of triaxial tests of unsaturated soil at constant water and air content by using an elasto-viscoplastic model, Proc. 1st European Conference on Unsaturated Soil, 735-741.

36) Rifa'i, A., Laloui, L. and Vulliet, L. (2002): Volume measurement in unsaturated triaxial test using liquid variation and image processing, Proc. 3rd Int. Conference on Unsaturated Soils, UNSAT 2002, Recife, Brazil (eds. by Juca, J. F. T., De Campos, Tacio M. P. and Marinho, Fernando A. M.), Balkema, 441-445.

37) Romero, E., Facio, J. A., Lioret, A., Gens, A. and Alonso, E. E. (1997): A new suction and temperature controlled triaxial apparatus, Proc. 14th ICSMFE, Hamburg, Balkema, 1, 185-188.

38) Sivakumar, V. (1993): A critical state framework for unsaturated soil, PhD Thesis, University of Sheffield.

39) Suzuki, H., Kodaka, H. and Oka, F. (2006): Mechanical properties of unsaturated silt under unexhausted and pore air pressure controlled condition, Proc. 41st Annual Meeting of JGS, Kagoshima, 323-324 (in Japanese).

40) Wheeler, S. J. and Sivakumar, V. (1995): An elasto-plastic critical state framework for unsaturated soil, Geotechnique, 45(1), 35-53.

41) Wheeler, S. J., Sharma, R. S. and Buisson, M. S. R. (2003): Coupling of hydraulic hysterisis and stress-strain behaviour in unsaturated soils, Geotechnique, 53(1), 41-54.

42) Wulfsohn, D., Adams, B. A. and Fredlund, D. G. (1998): Triaxial testing of unsaturated agricultural soils, J. Agric. Engineering. Res., 69, 317-330.

43) Yamamura, K. (1971): Soil engineering research of river embankment, Doctoral Thesis, Kyoto University, Japan (in Japanese). 